University of Nebraska - Lincoln

DigitalCommons@University of Nebraska - Lincoln

Geochemical Evidence for African Dust and Volcanic Ash Inputs to Terra Rossa Soils on Carbonate Reef Terraces, Northern Jamaica, West Indies

Daniel R. Muhs

US Geological Survey, dmuhs@usgs.gov

James R. Budahn

US Geological Survey

Follow this and additional works at: https://digitalcommons.unl.edu/usgsstaffpub

Part of the Earth Sciences Commons

Muhs, Daniel R. and Budahn, James R., "Geochemical Evidence for African Dust and Volcanic Ash Inputs to Terra Rossa Soils on Carbonate Reef Terraces, Northern Jamaica, West Indies" (2009). USGS Staff -Published Research. 172.

https://digitalcommons.unl.edu/usgsstaffpub/172

This Article is brought to you for free and open access by the US Geological Survey at DigitalCommons@University of Nebraska - Lincoln. It has been accepted for inclusion in USGS Staff -- Published Research by an authorized administrator of DigitalCommons@University of Nebraska - Lincoln. 


\title{
Geochemical evidence for African dust and volcanic ash inputs to terra rossa soils on carbonate reef terraces, northern Jamaica, West Indies
}

\author{
Daniel R. Muhs*, James R. Budahn \\ US Geological Survey, MS 980, Box 25046, Federal Center, Denver, CO 80225, USA
}

Available online 17 November 2007

\begin{abstract}
The origin of red or reddish-brown, clay-rich, "terra rossa" soils on limestone has been debated for decades. A traditional qualitative explanation for their formation has been the accumulation of insoluble residues as the limestone is progressively dissolved over time. However, this mode of formation often requires unrealistic or impossible amounts of carbonate dissolution. Therefore, where this mechanism is not viable and where local fluvial or colluvial inputs can be ruled out, an external source or sources must be involved in soil formation. On the north coast of the Caribbean island of Jamaica, we studied a sequence of terra rossa soils developed on emergent limestones thought to be of Quaternary age. The soils become progressively thicker, redder, more Fe- and Al-rich and Si-poor with elevation. Furthermore, although kaolinite is found in all the soils, the highest and oldest soils also contain boehmite. Major and trace element geochemistry shows that the host limestones and local igneous rocks are not likely source materials for the soils. Other trace elements, including the rare earth elements (REE), show that tephra from Central American volcanoes is not a likely source either. However, trace element geochemistry shows that airborne dust from Africa plus tephra from the Lesser Antilles island arc are possible source materials for the clay-rich soils. A third, as yet unidentified, source may also contribute to the soils. We hypothesize that older, more chemically mature Jamaican bauxites may have had a similar origin. The results add to the growing body of evidence of the importance of multiple parent materials, including far-traveled dust, to soil genesis.
\end{abstract}

Published by Elsevier Ltd.

\section{Introduction}

Red or reddish-brown, clay-rich soils ("terra rossa") and bauxites (Al-rich soils) on carbonate substrates are found on several continents and numerous islands in the Caribbean and western Atlantic, the Mediterranean, and the Pacific. The origin of these visually striking soils has been the subject of debate for decades. Schaetzl and Anderson (2005) review the possible modes of origin that have been proposed for terra rossa soils. In some cases, an in situ origin of the soils is not difficult to ascertain because there is abundant non-carbonate material in the host sediment, and weathering of these primary minerals can explain the clay-rich nature of the soils. Problems arise, however, when attempts are made to determine the origin of clay-rich soils on carbonate rocks of high purity. For example, Tracey et al. (1964) and Birkeland (1999) showed

\footnotetext{
*Corresponding author. Tel./fax: + 13032367919.

E-mail address: dmuhs@usgs.gov (D.R. Muhs).
}

that unreasonable amounts of carbonate would be required to produce soils by this process on carbonate terrains in the Marianas Islands (Guam and Rota) of the Pacific. In the case of Rota Island, the entire island would have to have been dissolved in order to produce the observed soil profiles, a physical impossibility (Birkeland, 1999).

Muhs et al. (1987) summarize four possible modes of origin that have been described by previous workers who have studied soils and bauxites on Caribbean and western Atlantic carbonate islands, or islands with significant carbonate terrains. One is the traditional residual hypothesis, with accumulation of insoluble residues from dissolution of the host carbonate rock. A second mechanism is transportation of fluvially entrained clays from topographically higher positions (local, external sources) to lower carbonate surfaces. Two other processes require sediment inputs from distant, external sources. One of these is weathering of volcanic ash that has fallen on the carbonate surfaces and the other is weathering of fine-grained eolian sediments (dust) that have origins in distant regions. 
In the Caribbean basin and western Atlantic Ocean region, there are many carbonate islands, or at least islands with significant carbonate terrains, including the Florida Keys, Bermuda, Bahamas, Barbados, and parts of Jamaica (Fig. 1). Approximately two-thirds of Jamaica (Fig. 2) is underlain by limestone bedrock of Tertiary or Quaternary

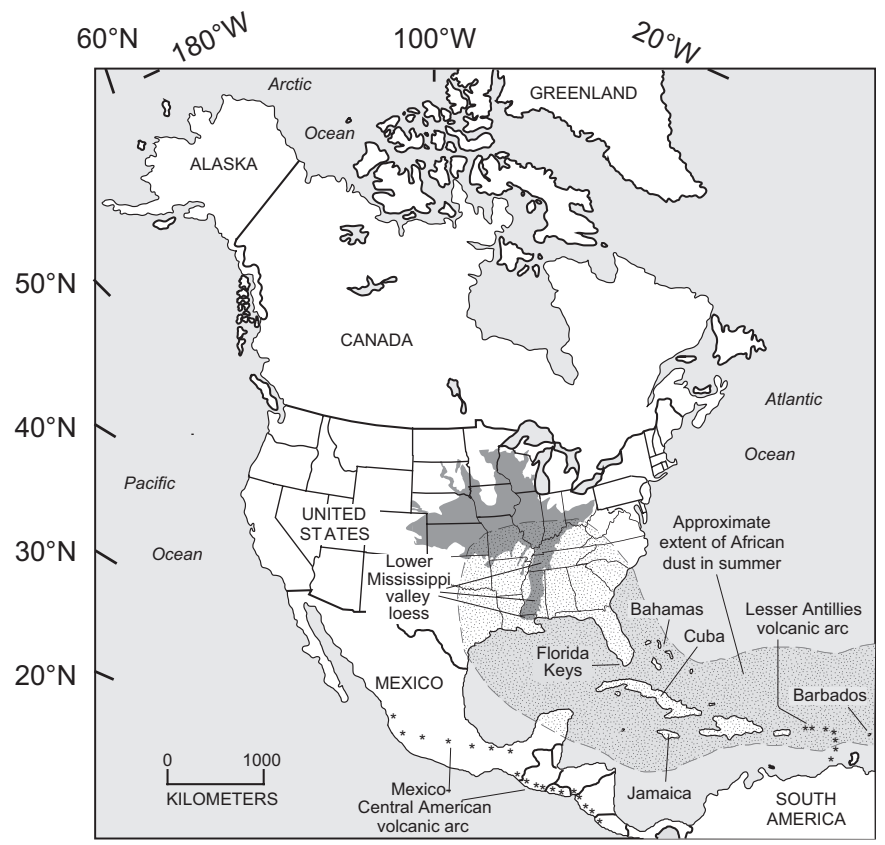

Fig. 1. Map of North America, the Caribbean basin, Jamaica and other islands referred to in text. Also shown are the distribution of loess (from compilations of Bettis et al., 2003; Muhs and Bettis, 2003) and approximate extent of African dust in summer, based on 1983-1992 TOMS satellite data and studies by Prospero and Carlson (1972), Prospero (1999), Perry et al. (1997), and Kallos et al. (2006). age (McFarlane, 1977). The limestones of Jamaica host widespread, thick, red, and clay-rich terra rossa soils and bauxites (Fig. 2). Indeed, Jamaica is one of the world's leading producers of bauxite mined for aluminum (Patterson et al., 1986). In this paper, we examine the properties of terra rossa soils on some of the younger carbonate substrates of Jamaica. A recent study reports varying degrees of influence of volcanic ash and African dust on the genesis of soils on other carbonate islands of the Caribbean and western Atlantic (Muhs et al., 2007a). Here, we test the hypothesis that Jamaican soils may have been similarly affected by long-range transport of African dust.

\section{Previous studies of soil and bauxite genesis on Jamaica}

\subsection{Residual accumulation from limestone impurities}

Scholten and Andriesse (1986) invoked a residual origin for reddish-brown, clay-rich soils developed on Tertiary limestone in the western part of Jamaica. Many previous investigators have appealed to the same process to explain the origin of Jamaican bauxite (Schmedeman, 1948, 1950; Hartman, 1955; Hill, 1955; Hose, 1963; Clarke, 1966; Sinclair, 1967, 1976). The main arguments against a residual origin are that there are simply too few impurities in most island carbonates to account for the amount of observed soil. Hartman (1955) reports that much of the White Limestone Group (Tertiary) and Coastal Limestone Group (Tertiary and Quaternary) rocks are composed of carbonates of exceptional purity, with CaO-plus-loss-onignition contents exceeding $99 \%$. Thus, formation of a meter-thick terra rossa soil could require complete dissolution of $100 \mathrm{~m}$ of limestone.

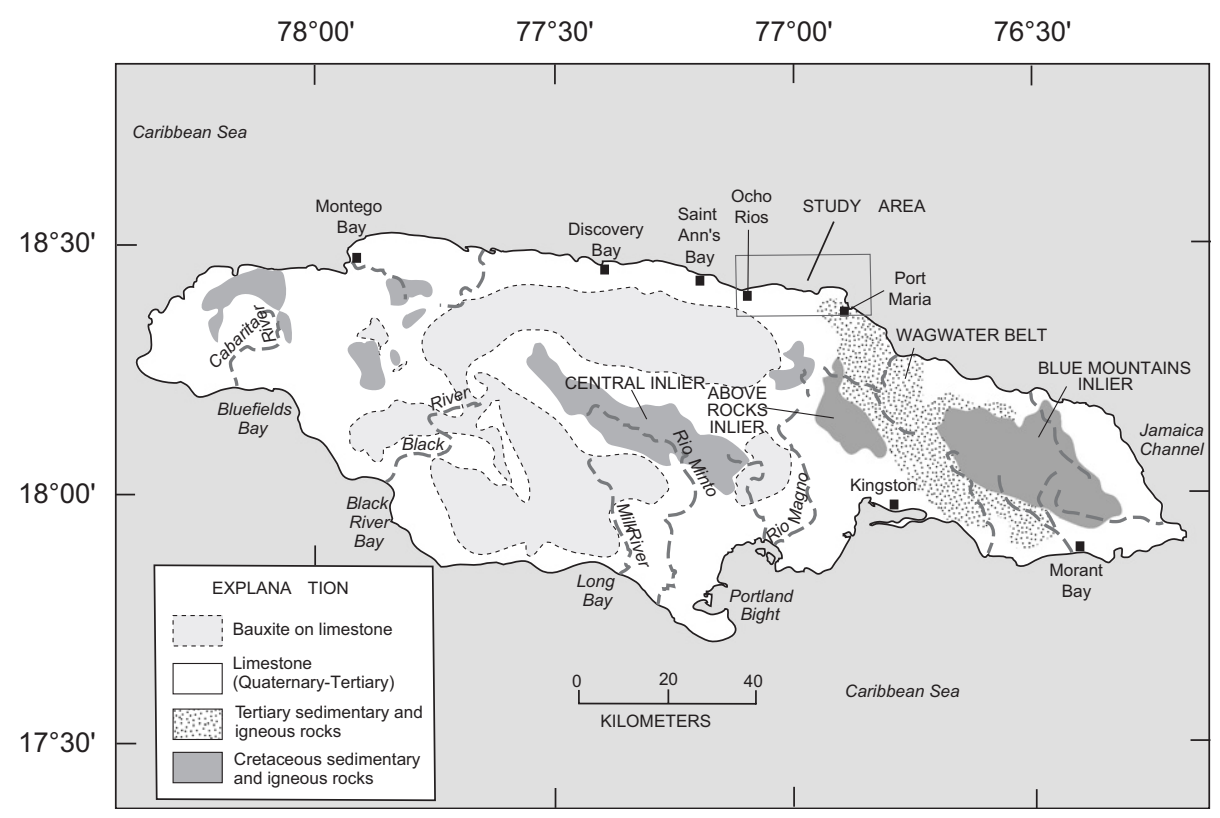

Fig. 2. Map of simplified bedrock geology of Jamaica (from McFarlane, 1977; Jackson et al., 1989) showing distribution of limestone-hosted bauxite (modified from Lyew-Ayee and Stewart, 1982) and major geographic features. 


\subsection{Fluvial origin from higher landscapes}

A fluvial origin has been used to explain some occurrences of bauxite on carbonate rocks in Jamaica and Haiti (Zans, 1959; Kelly, 1961; Chubb, 1963; Boulegue et al., 1989). On Haiti, Boulegue et al. (1989) propose a mechanism whereby kaolinite develops as an alteration product of basalt weathering and is subsequently transported to, and trapped in, karst depressions in younger limestones. Following this "entrapment" in karst depressions, dissolution of silica results in the alteration of kaolinite to gibbsite and the formation of bauxite. Ahmad et al. (1966) propose that insoluble residues in limestone are the ultimate source of bauxite soils on Jamaica, but also recognize that soils are far too thick to explain accumulation by this mechanism alone. They hypothesize that the great thicknesses of bauxitic soils are a result of redistribution by erosion and sedimentation. However, because bauxite covers a significant portion of Jamaica and is present on some of the highest parts of the western half of the island (Fig. 2), it is difficult to envision this process as an explanation for many bauxite deposits.

\subsection{Weathering of volcanic ash}

Because many low-latitude carbonate islands are adjacent to active volcanic island arcs in the Caribbean, volcanic ash is a potential source of soil clays. Bauxites on pre-Quaternary limestones of Jamaica have long been considered to have developed primarily from Miocene volcanic ash falls (Burns, 1961; Waterman, 1962; Comer, 1974, 1984; Comer et al., 1980).

Jamaica is situated approximately midway between the active Lesser Antilles island arc and the active volcanic arcs of Central America and Mexico, $\sim 1500 \mathrm{~km}$ from each chain (Fig. 1). Isopach maps of late Quaternary tephras from Central American and Mexican volcanoes show dispersal patterns mainly to the north, into the Gulf of Mexico and to the south, into the eastern Pacific Ocean (Drexler et al., 1980). Little ash from this volcanic chain appears to be deposited eastward in the Caribbean Sea, although Drexler et al. (1980, their Fig. 6) show a trace amount of ash recorded in a core taken in waters to the north of Cuba. Studies of the 1982 eruption of El Chichón volcano in Mexico show that ash reached altitudes as high as $17-31 \mathrm{~km}$ in the stratosphere (Matson, 1984). In the latitudes of El Chichón and Jamaica $\left(17-18^{\circ} \mathrm{N}\right)$, this means that ash dispersal could have taken place either to the west, in the stratosphere, and/or to the east in the upper troposphere (Sigurdsson et al., 1980). Indeed, satellite images taken on 4 April 1982 record an ash cloud moving from El Chichón to the east, in the direction of Cuba and Jamaica (Matson, 1984).

It is also possible that ash erupted from the Lesser Antilles island arc (Fig. 1) can reach Jamaica, some $1500 \mathrm{~km}$ to the west of the volcanic arc. Evidence from deep-sea cores indicates that ash falls in the Caribbean region have been common throughout the Quaternary (Sigurdsson et al., 1980; Reid et al., 1996). Clay-rich soils on Quaternary reef terraces of Barbados, east of the Lesser Antilles island arc, appear to have developed to a great extent from volcanic ash falls, based on both isotopic studies (Borg and Banner, 1996) and trace-elementgeochemical data (Muhs et al., 2007a). On the other hand, Sigurdsson et al. (1980) point out that ash from Quaternary volcanic eruptions in the Lesser Antilles island arc is transported mainly to the east, due to ejection of volcanic particles into the upper troposphere, where winds are westerly. Thus, whereas this mechanism may be viable for soil genesis on Barbados (east of the island arc), it is less certain as a process for Jamaica (west of the arc). Nevertheless, Carey and Sigurdsson (1980) report ash in a marine core $1200 \mathrm{~km}$ to the west of the Lesser Antilles island arc. They suggest that ash dispersal to the west is possible via transport in the stratospheric upper-air easterlies, above an altitude of $17 \mathrm{~km}$.

\subsection{Derivation of soils from airborne dust}

A potential source of soil parent material for Jamaica and other islands in this part of the Caribbean is African dust, carried west across the Atlantic Ocean (Fig. 1). The dust-bearing "Saharan Air Layer," near its sources in Africa, can reach altitudes as high as $5-7 \mathrm{~km}$. Farther west, dust concentrations are greatest at altitudes of $1.5-3.7 \mathrm{~km}$, within the lower troposphere and the zone of the northeasterly trade winds. Dust from Saharan storms can reach the island of Barbados (Fig. 1) within about a week after departure from the western African coast (Prospero et al., 1970, 1981; Prospero and Carlson, 1972; Prospero and Lamb, 2003). Based on analyses of satellite imagery, aerosol sampling networks, and back-trajectory calculations, the sources of this eolian dust are the Sahara and Sahel regions of Africa (Prospero et al., 1970, 1981, 2002; Prospero and Nees, 1986; Goudie and Middleton, 2001; Caquineau et al., 2002). In summer, dust from Africa is transported at least as far north as Florida (Prospero and Nees, 1987; Prospero, 1999) and very likely into the central and eastern United States (Perry et al., 1997; Kallos et al., 2006).

Interestingly, almost four decades ago, Land and Epstein (1970, p. 191) hypothesized that African dust could be a parent material for terra rossa soils on emergent reefs of Jamaica. Lyew-Ayee (1984) pointed out the geochemical similarity between Cuban bauxites and dust collected in the Caribbean, when portrayed on a $\mathrm{TiO}_{2}-\mathrm{Al}_{2} \mathrm{O}_{3}-\mathrm{Fe}_{2} \mathrm{O}_{3}$ ternary diagram. Pye (1988) suggests, on the basis of work in Australia by Brimhall et al. (1988), that African dust could be the source of aluminum enrichment in Jamaican bauxites. Muhs et al. (1990) report the same possibility for younger soils on Jamaican limestones, which we reexamine in the present paper.

Another potential source of dust to Jamaica is the distal, fine-grained component of North American loess. Loess in 


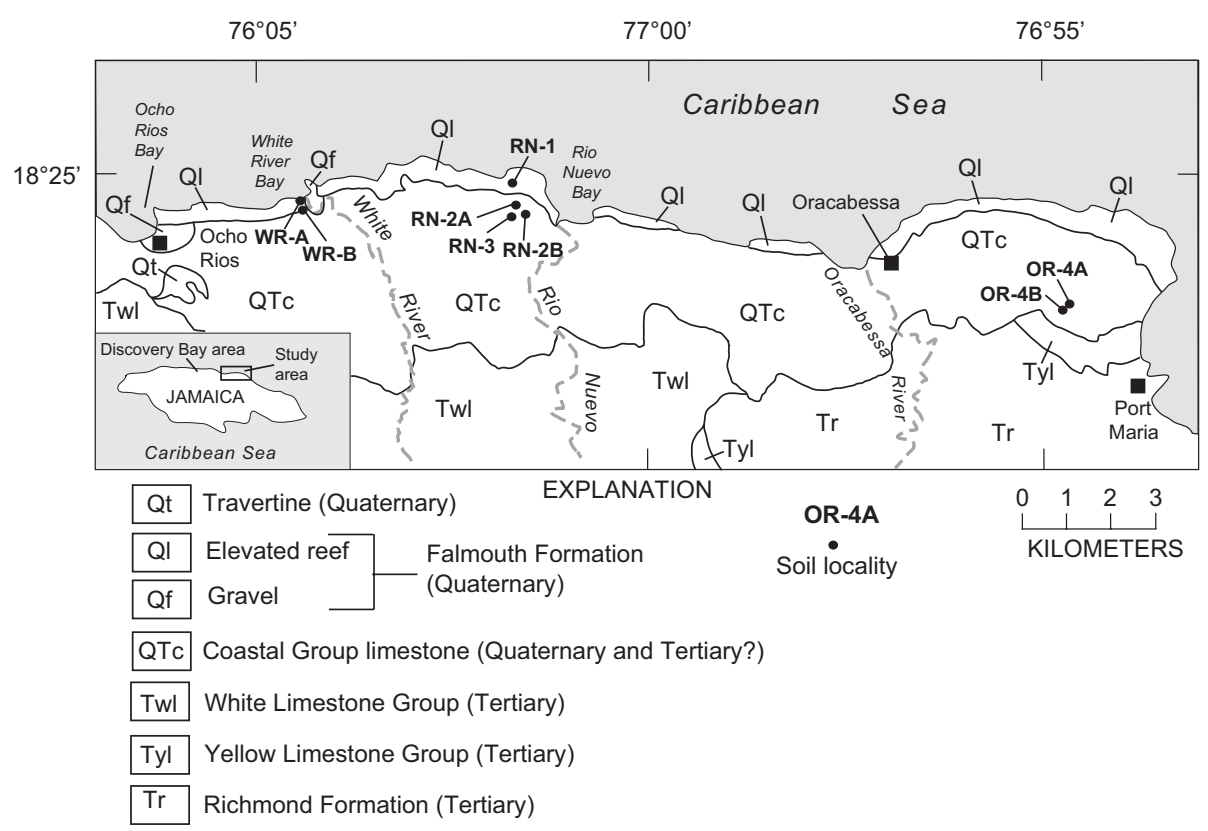

Fig. 3. Map of a portion of the northern coast of Jamaica, showing Tertiary and Quaternary geology. Redrawn from the Ocho Rios and Port Maria 1:50,000 geologic quadrangles (Henry, 1978a, b).

the lower Mississippi River valley was deposited mostly to the east of the river, indicating winds from the west or northwest, consistent with paleowinds documented elsewhere in central North America (Bettis et al., 2003; Muhs and Bettis, 2003). Because Jamaica is situated to the southeast of this major loess belt, it is possible that the finegrained component (e.g., particles $<20 \mu \mathrm{m}$ diameter) of this loess might have been transported southeastward and provided soil parent material for the island. Data presented by Muhs et al. (2007a) indicate that soils on the Florida Keys and the Bahamas may have been affected by both African dust and North American loess.

\section{Study area, geology, and uncertainties in geochronology}

We studied soils on the north coast of Jamaica, where flat-lying carbonate rocks of Quaternary and Tertiary age are best exposed (Zans et al., 1962; McFarlane, 1977). The most detailed studies of young carbonates on Jamaica have been conducted on the north-central coast, near Discovery Bay (Fig. 2). Land and Epstein (1970) and Land $(1973,1991)$ identified two emergent reef units in this area, called the Falmouth Formation and Hope Gate Formation. The two reefs form marine terrace landforms and have been mapped in the Discovery Bay area by Boss and Liddell (1987). The upper surface of the Falmouth Formation is $\sim 5 \mathrm{~m}$ above sea level (a.s.l.) and abuts the older, topographically higher Hope Gate Formation. U-series ages of corals from the Falmouth Formation indicate that this unit dates to the last interglacial period, $\sim 125,000$ yr BP (Moore and Somayjulu, 1974; Szabo, 1979). Previously, the Hope Gate Formation was thought to be middle Pleistocene (Land, 1973); however, Land
(1991) reported ${ }^{87} \mathrm{Sr} /{ }^{86} \mathrm{Sr}$ values from carbonates in the Hope Gate Formation that suggest latest Pliocene to earliest Pleistocene ages $(\sim 2 \mathrm{Ma})$. This older age estimate is consistent with the fauna of the formation, which includes a number of extinct species (Stemann et al., 2004).

A greater number of emergent reefs can be found farther east along the northern coast of Jamaica between Ocho Rios and Port Maria (Figs. 3 and 4). On the 1:50,000-scale geologic maps of this area, only the Falmouth Formation is mapped separately; older carbonate reefs are included within the Coastal Group Limestone shown in Fig. 3 (Henry, 1978a, b). Nevertheless, Zans et al. (1962), Cant (1970, 1972, 1973), and Horsfield $(1973,1975)$ report four prominent, emergent reef terraces between the Rio NuevoOracabessa area and Port Maria (Fig. 4). Cant (1970) reports these reefs as $\sim 1-15 \mathrm{~m}$ a.s.l. (terrace 1 ), $58-70 \mathrm{~m}$ a.s.1. (terrace 2), $94-119 \mathrm{~m}$ a.s.1. (terrace 3 ), and $131-180 \mathrm{~m}$ a.s.1. (terrace 4), with perhaps three additional (minor) terraces at intermediate elevations. Cant $(1970,1972,1973)$ correlates terrace 1 in the Oracabessa area with the Falmouth Formation $(\sim 125,000 \mathrm{yr}$ BP), and terrace 2 with the Hope Gate Formation, which he estimates to be $\sim 200,000-310,000 \mathrm{yr} \mathrm{BP}$, based on an assumption of a constant uplift rate. Correlation of terrace 2 at Oracabessa was made before Land (1991) reported his Sr-isotope data. Thus, if Cant's $(1970,1972,1973)$ uplift rate age estimate is correct, terrace 2 does not correlate with Land's (1991) $\sim 2 \mathrm{Ma}$ Hope Gate Formation. Cant (1970) reports that terrace 4 at Oracabessa has sediments with reversed magnetism and it is therefore older than the Brunhes-Matuyama paleomagnetic boundary at about 780,000 yr BP (Spell and McDougall, 1992). When we visited Cant's $(1970,1972,1973)$ terrace sequence near 


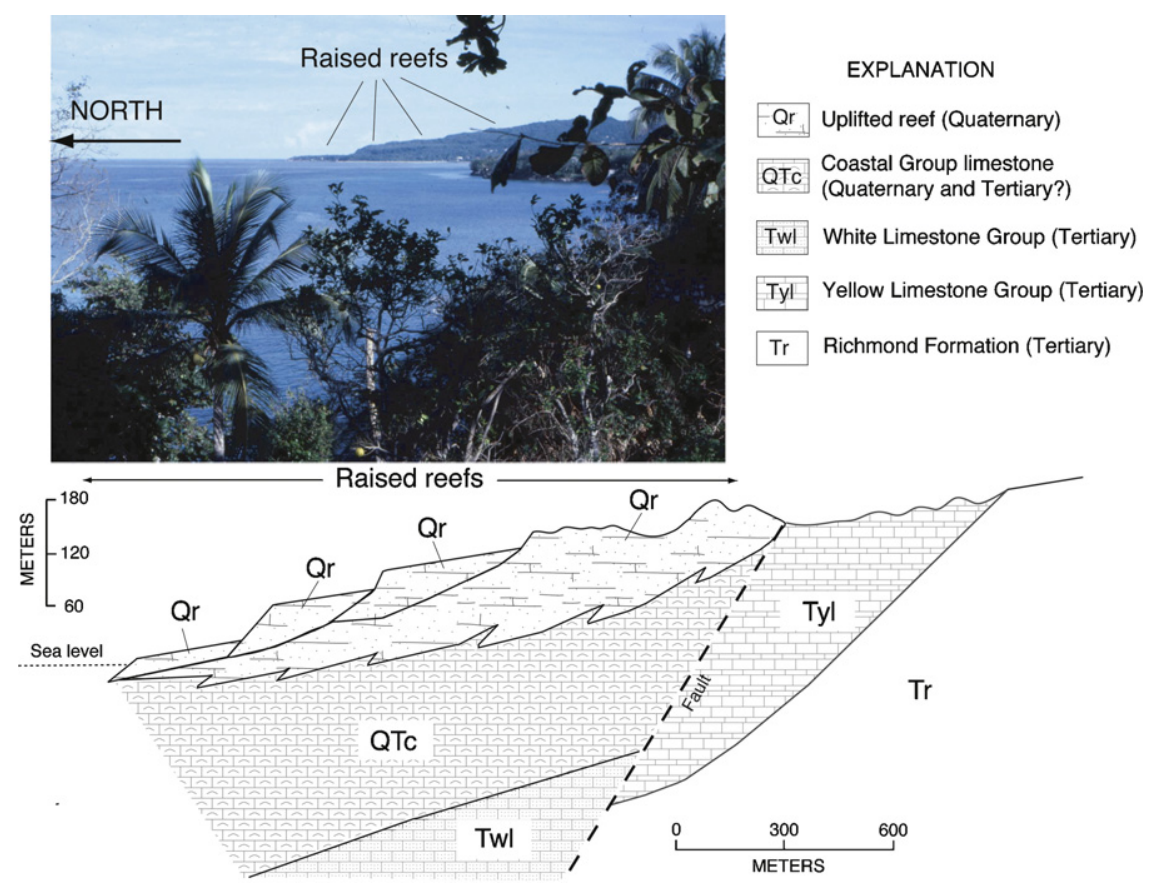

Fig. 4. Raised reefs of northern Jamaica. Photograph shows view to the east, just east of Oracabessa (see Fig. 3 for location). Drawing shows geologic cross section of raised reefs and underlying bedrock units in the area photographed above, redrawn from Cant (1970).

Oracabessa, we were unable to find undisturbed or uneroded soils on many of the lower terraces. Indeed, on the outer edge of the lowest terrace, less than a meter above sea level, soils have been completely removed by wave erosion. However, we did find two uneroded and undisturbed soils on Cant's terrace 4, at an elevation of $\sim 150 \mathrm{~m}$ (OR-4A and OR-4B).

The best-exposed sequence of uneroded soils that we found is on what we interpret to be emergent reef terraces near Rio Nuevo Bay (Fig. 4). Exposures of the carbonate facies here are very shallow, so it was not possible to ascertain whether these represent true constructional reefs of Quaternary age, wave-cut platforms beveled on Quaternary reefs, or wave-cut platforms eroded on older, Tertiary carbonate rocks. All fossil material that we found was recrystallized, precluding age determinations by either U-series or Sr-isotope methods. We stress, therefore, that our interpretations are based primarily on geomorphic relations, interpretations of what we assume to be terrace inner edge elevations, and correlation to dated terraces to the east (Oracabessa) and west (Discovery Bay). Much more detailed mapping, subsurface exploration, and geochronology are needed in this area before firm conclusions can be drawn about terrace chronology.

At the Rio Nuevo Bay sequence, we measured elevations of what we interpret to be three emergent reef terraces, by hand-level and from 1:50,000 topographic maps. The lowermost terrace has an outer-edge elevation $\sim 15 \mathrm{~m}$ a.s.l. and an apparent inner edge near $\sim 30 \mathrm{~m}$ elevation, where the coastal road crosses it. This terrace is $\sim 250 \mathrm{~m}$ wide and is mapped as the reef facies of the 125,000-yr-old Falmouth Formation by Henry (1978b). Soil profile RN-1 was collected from this surface, about $200 \mathrm{~m}$ seaward of the coastal road. Although this landform is mapped as the reef facies of the Falmouth Formation, we found rounded, carbonate-coated cobbles of microcrystalline quartz throughout the RN-1 profile, suggesting that this soil may have developed on the gravel facies of the formation. The next highest terrace surface has an outer edge that is $\sim 37 \mathrm{~m}$ a.s.1., a width of $\sim 400 \mathrm{~m}$, and an apparent inner edge elevation of $\sim 42 \mathrm{~m}$. Soil profiles $\mathrm{RN}-2 \mathrm{~A}$ and $\mathrm{RN}-2 \mathrm{~B}$ were collected from this surface. Above the 42-m-high terrace, there is yet another terrace surface that has an outer edge at $\sim 50 \mathrm{~m}$ a.s. 1 . This surface is $\sim 270 \mathrm{~m}$ wide, and has an apparent inner edge elevation of at least $\sim 64 \mathrm{~m}$. The inner edge elevation measurement is only a minimum estimate, because a wedge of well-rounded, beach-derived (?) cobbles (composed of microcrystalline quartz) mantles the landward margin of the terrace. Soil profile RN-3 was collected from the midpoint of the terrace surface.

We estimate possible ages of the two higher terraces using a late Quaternary uplift rate of $0.19 \mathrm{~m}$ per $1000 \mathrm{yr}$ from the $\sim 30$-m-high terrace and the higher terraces' shoreline angle elevations. Although we infer that these terraces formed initially as constructional reefs, they also have a geomorphic expression suggesting they may have been modified subsequently as wave-cut platforms. Speed and Cheng (2004) report that many of the marine terraces on Barbados, although partly formed by reef construction, also have a partly erosional origin, characterized by wavecut platforms, sea cliffs, and shoreline angles that mark the platform-cliff junction. We derive an uplift rate of $\sim 0.19 \mathrm{~m}$ per $1000 \mathrm{yr}$ by using the $\sim 30$-m-high elevation of what appears to be the shoreline angle of the Falmouth 


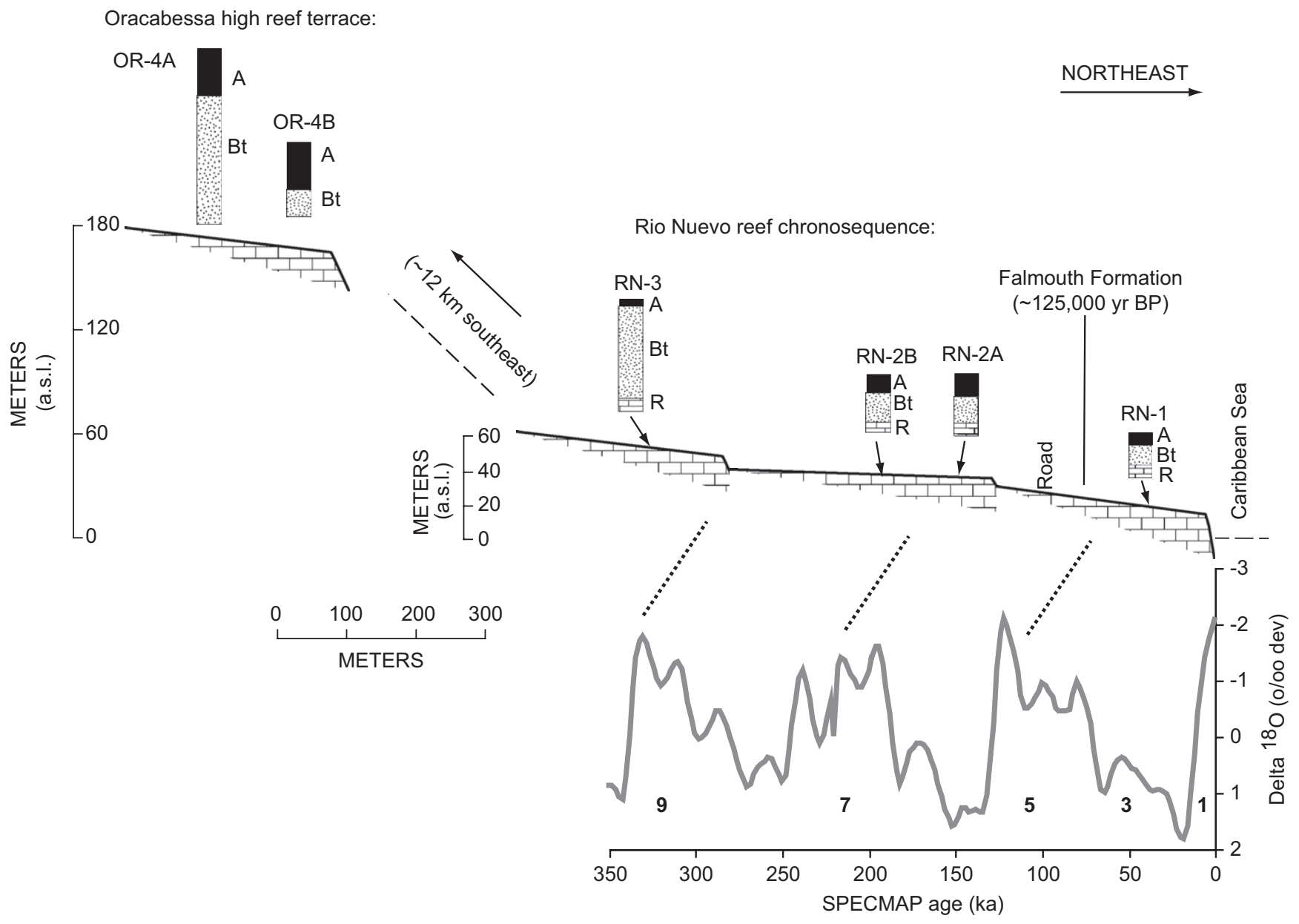

Fig. 5. Soil chronosequence on terraces near Rio Nuevo and possible correlation of interglacial reef terraces with the SPECMAP oxygen isotope record (Imbrie et al., 1984).

Formation terrace surface, an assumption that sea level was $\sim 6 \mathrm{~m}$ higher than present at the time of terrace formation (see review in Muhs, 2002), and an age of $\sim 125,000$ yr. This relatively low uplift rate is consistent with the predominantly strike-slip transpressional tectonic style that has affected Jamaica during the Neogene (Burke et al., 1980). If we assume that sea levels were close to present for the two higher $(\sim 42$ and $\sim 64 \mathrm{~m})$ terraces, their (assumed) shoreline-angle elevations and the calculated uplift rate yield estimated ages of $\sim 220,000$ and $\sim 330,000 \mathrm{yr}$, which suggest possible correlation with interglacial marine isotope stages 7 and 9, respectively (Fig. 5). Nevertheless, we emphasize that these age estimates are tentative and are used here in the context of a working hypothesis rather than a firm chronology.

Near White River Bay, a carbonate reef is exposed at the junction of the coastal road and a smaller road leading to the south (Fig. 3). This road cut had, in early 1985, a lateral exposure of $\sim 60 \mathrm{~m}$, and showed a seaward-to-landward reef facies change in the sediment (Fig. 6). Henry (1978b) mapped as these sediments as reef facies of the $\sim 125,000$ yr-old Falmouth Formation. The outer edge, near the coastal road, hosts at least $4 \mathrm{~m}$ of reef-crest facies, with corals in growth position (although recrystallized), including what appear to be Montastrea sp. and Diploria sp. (Fig. 7). Landward of this facies, there is a narrow zone of coral rubble, and farthest landward, there is a layer, at least $\sim 1 \mathrm{~m}$ thick, of carbonate sand that we interpret to be a backreef, lagoonal facies. Soil profile WR-A was collected on the reef-crest facies and profile WR-B was collected on the lagoonal facies.

\section{Properties of soils on the northern coast of Jamaica}

\subsection{Methods}

Soils were described in the field using standard soil terminology as practiced in the USA (see Birkeland, 1999). Samples were collected and subsequently analyzed by soil horizon. For clay mineralogy, the $<2 \mu \mathrm{m}$ fraction was separated by sedimentation after removal of carbonates with acetic acid (buffered to a $\mathrm{pH}$ of 5.0), removal of organic matter by $\mathrm{H}_{2} \mathrm{O}_{2}$, dispersion with Na-pyrophosphate, and separation of sands $(>53 \mu \mathrm{m})$ by wet-sieving. Clays were given an oriented mount on glass slides and X-rayed three times: air-dry, with ethylene-glycol 
solvation, and heat-treated $\left(550{ }^{\circ} \mathrm{C}\right.$ for $\left.2 \mathrm{~h}\right)$. Identification of clay mineral species follows the techniques of Moore and Reynolds (1997). Major element chemistry was
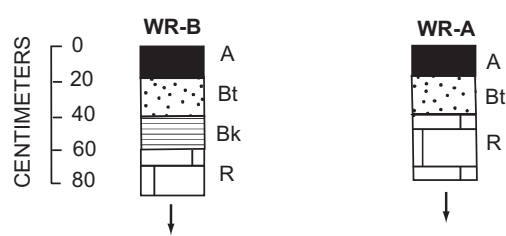

NORTH

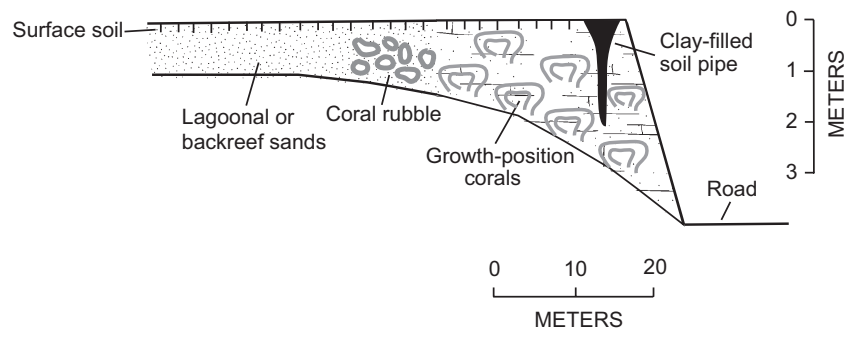

Fig. 6. Cross section of reef facies and soils sampled in road cut near White River Bay (see Fig. 3 for location). conducted on bulk, pulverized soil samples in laboratories of the USGS using wavelength-dispersive X-ray fluorescence (Taggart et al., 1982). Trace element chemistry, including the rare earth elements (REE) was conducted on splits of bulk samples using instrumental neutron activation analysis (Budahn and Wandless, 2002). The one exception to this is $\mathrm{Y}$, which was determined by energydispersive X-ray fluorescence; these data were previously reported by Muhs et al. (1990).

\subsection{Soil morphology}

The morphology of the soils we studied reflects their ages estimated from the uplift rate (Table 1). Older soils are thicker, redder, and more clay-rich than are younger soils. In the Rio Nuevo area, profile RN-1, on what we infer to be the $\sim 125,000$-yr-old last interglacial terrace, has a shallow $(\sim 26 \mathrm{~cm})$ profile with mostly $10 \mathrm{YR}$ hues in the B horizon. The B horizon has clayey textures, but the angular-tosubangular blocky structure in this horizon is weak. Profiles RN-2A and RN-2B, on the next highest surface, have deeper profiles $(37-40 \mathrm{~cm})$, redder (5YR to $2.5 \mathrm{YR}$ )

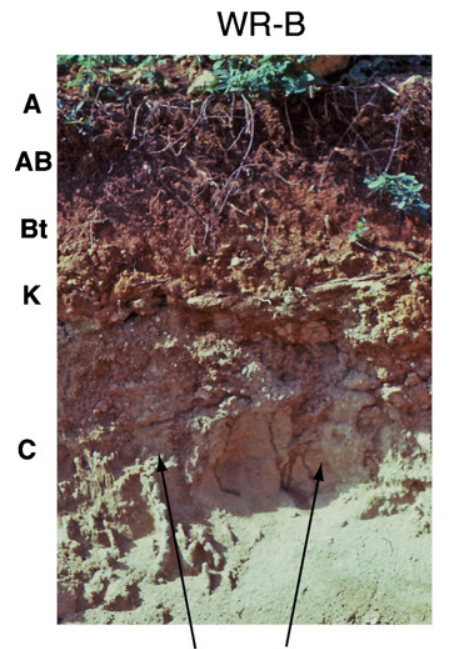

Lagoonal or back-reef sands of the Falmouth Formation $(125,000$ yr BP)

RN-2A

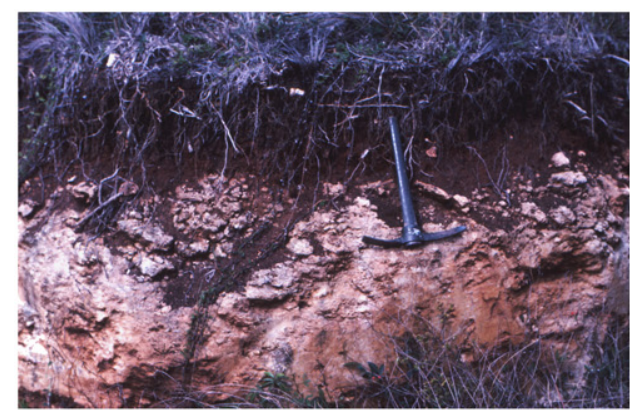

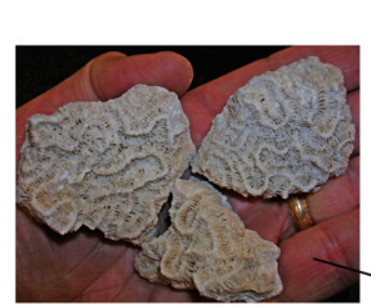

Diploria sp.

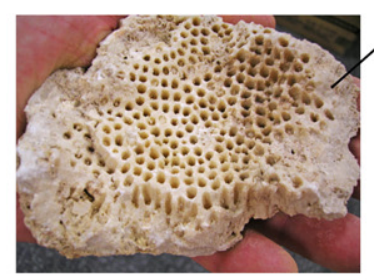

Montastrea sp.

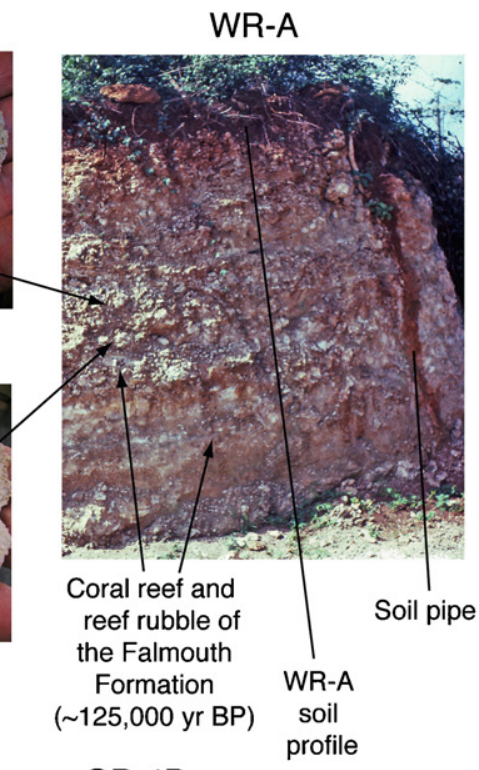

OR-4B

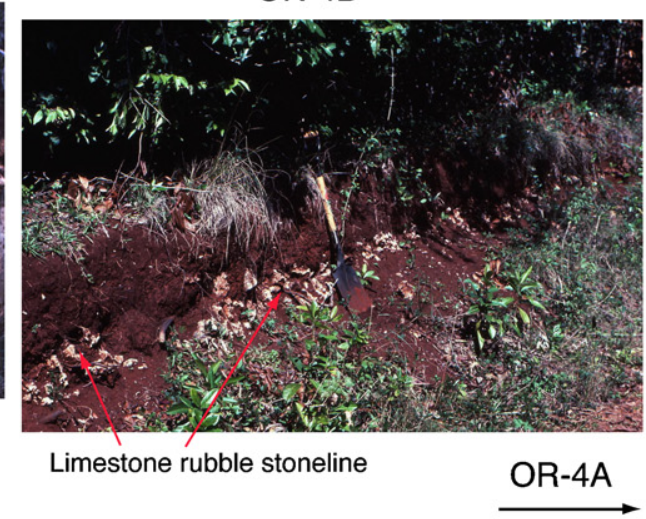

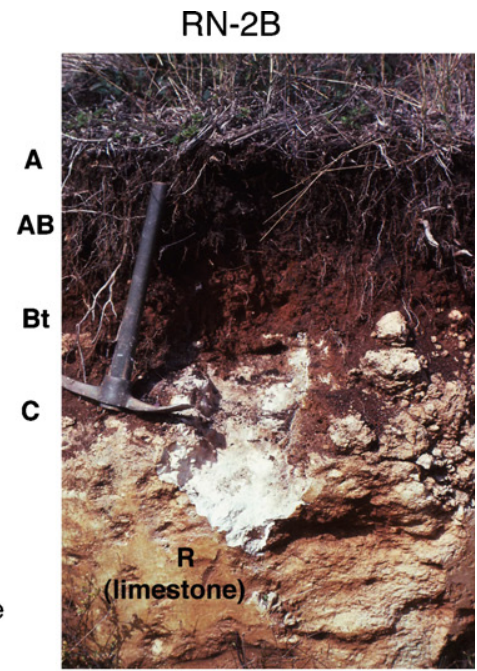

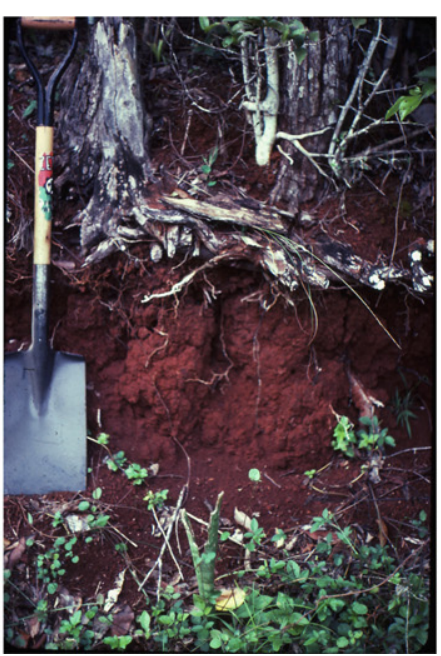

Fig. 7. Photographs showing some of the soil profiles with their master soil horizons, as well as corals collected from the Falmouth Formation reef at WRA (see Fig. 3 for localities). 
Table 1

Morphology and major element geochemistry of carbonate-reef hosted soils, northern coast of Jamaica

\begin{tabular}{|c|c|c|c|c|c|c|c|c|c|c|c|c|c|c|c|c|c|c|c|c|}
\hline Profile\# & $\begin{array}{l}\text { Inner edge } \\
\text { elev. (m) }\end{array}$ & $\begin{array}{l}\text { Estimated } \\
\text { age (ka) }\end{array}$ & Horizon & Depth (cm) & $\begin{array}{l}\text { Color (dry, } \\
\text { pulv.) }\end{array}$ & Texture & Structure & Boundary & $\begin{array}{l}\text { Other } \\
\text { features }\end{array}$ & $\begin{array}{l}\mathrm{SiO}_{2} \\
(\%)\end{array}$ & $\begin{array}{l}\mathrm{Al}_{2} \mathrm{O}_{3} \\
(\%)\end{array}$ & $\begin{array}{l}\mathrm{Fe}_{2} \mathrm{O}_{3} \\
(\%)\end{array}$ & $\begin{array}{l}\mathrm{MgO} \\
(\%)\end{array}$ & $\begin{array}{l}\mathrm{CaO} \\
(\%)\end{array}$ & $\begin{array}{l}\mathrm{Na}_{2} \mathrm{O} \\
(\%)\end{array}$ & $\begin{array}{l}\mathrm{K}_{2} \mathrm{O} \\
(\%)\end{array}$ & $\begin{array}{l}\mathrm{TiO}_{2} \\
(\%)\end{array}$ & $\begin{array}{l}\mathrm{P}_{2} \mathrm{O}_{5} \\
(\%)\end{array}$ & $\begin{array}{l}\mathrm{MnO} \\
(\%)\end{array}$ & $\begin{array}{l}\text { LOI } \\
(\%)\end{array}$ \\
\hline \multicolumn{21}{|c|}{ White River area } \\
\hline WR-A & $\sim 8$ & $\sim 125 ?$ & Ap & $0-13$ & $5 \mathrm{YR} 4 / 3$ & $\mathrm{cl}$ & $\mathrm{m}, \mathrm{f}-\mathrm{c}, \mathrm{abk}$ & gw & & 50.8 & 19.3 & 8.62 & 0.67 & 0.68 & 0.27 & 0.57 & 1.21 & 0.22 & 0.29 & 17.6 \\
\hline WR-A & & & $\mathrm{AB}$ & $13-25$ & $5 Y \mathrm{YR} 5 / 4$ & $\mathrm{cl}$ & $\mathrm{w}, \mathrm{c}, \mathrm{abk}$ & $\mathrm{gw}$ & & 48.9 & 21.3 & 9.08 & 0.69 & 0.59 & 0.26 & 0.53 & 1.12 & 0.18 & 0.22 & 16.4 \\
\hline WR-A & & & $\mathrm{Bt}$ & $25-40$ & 5 YR $5 / 6$ & $\mathrm{cl}$ & $\mathrm{w}, \mathrm{c}, \mathrm{abk}$ & aw & $\mathrm{k}$ & 45.5 & 24.8 & 9.90 & 0.78 & 0.59 & 0.26 & 0.53 & 0.98 & 0.17 & 0.11 & 16.2 \\
\hline WR-A & & & $\mathrm{R}$ & $40+$ & & & & & & & & & & & & & & & & \\
\hline WR-B & $\sim 8$ & $\sim 125 ?$ & A & $0-10$ & $5 \mathrm{YR} 5 / 2$ & scl & $\mathrm{s}, \mathrm{m}-\mathrm{c}, \mathrm{abk}$ & cs & & 45.6 & 19.6 & 8.43 & 0.80 & 1.94 & 0.18 & 0.51 & 1.01 & 0.21 & 0.26 & 21.3 \\
\hline WR-B & & & $\mathrm{AB}$ & $10-19$ & 7.5 YR $5 / 4$ & $\mathrm{scl}$ & $\mathrm{m}, \mathrm{m}-\mathrm{c}, \mathrm{sbk}$ & $\mathrm{cw}$ & & 39.0 & 16.9 & 7.04 & 0.71 & 11.3 & 0.17 & 0.46 & 0.77 & 0.16 & 0.18 & 23.9 \\
\hline WR-B & & & Bt1 & $19-27$ & $7.5 \mathrm{YR} 6 / 4$ & scl & $\mathrm{w}, \mathrm{f}-\mathrm{m}, \mathrm{sbk}$ & $\mathrm{gw}$ & & 16.2 & 7.69 & 3.01 & 0.50 & 37.6 & $<0.15$ & 0.23 & 0.28 & 0.10 & 0.03 & 34.7 \\
\hline WR-B & & & Bt2 & $27-34$ & $7.5 \mathrm{YR} 8 / 3$ & $\mathrm{scl}$ & $\mathrm{w}, \mathrm{f}-\mathrm{m}, \mathrm{sbk}$ & $\mathrm{gw}$ & $\begin{array}{l}\mathrm{k}, \mathrm{Bk} \\
\text { frags }\end{array}$ & 14.0 & 7.04 & 2.81 & 0.47 & 39.4 & $<0.15$ & 0.17 & 0.26 & 0.11 & 0.03 & 36.5 \\
\hline WR-B & & & $\mathrm{Bt} 3$ & $34-41$ & $7.5 \mathrm{YR} 8 / 3$ & scl & $\mathrm{w}, \mathrm{m}-\mathrm{c}, \mathrm{sbk}$ & $\mathrm{cw}$ & & 10.4 & 5.36 & 2.15 & 0.40 & 43.1 & $<0.15$ & 0.12 & 0.21 & 0.11 & $<0.02$ & 38.4 \\
\hline WR-B & & & $\mathrm{Bk}$ & $41-45$ & $7.5 \mathrm{YR} 8 / 1$ & & massive & $\mathrm{cw}$ & & 0.89 & 0.32 & $<0.04$ & 0.33 & 55.2 & $<0.15$ & 0.03 & $<0.02$ & 0.06 & $<0.02$ & 43.7 \\
\hline WR-B & & & $\mathrm{CBk}$ & $45-66$ & $10 \mathrm{YR} 8 / 2$ & & massive & $\mathrm{cw}$ & & 3.63 & 0.65 & 0.15 & 0.33 & 54.4 & $<0.15$ & 0.12 & $<0.02$ & $<0.05$ & $<0.02$ & 41.3 \\
\hline WR-B & & & $\mathrm{C}$ & $66+$ & 10 YR $8 / 2$ & & single grain & & & 3.31 & 0.72 & 0.20 & 0.33 & 54.2 & $<0.15$ & 0.13 & $<0.02$ & $<0.05$ & $<0.02$ & 40.8 \\
\hline \multicolumn{21}{|c|}{ Rio Nuevo area } \\
\hline $\mathrm{RN}-1$ & $\sim 30$ & $\sim 125 ?$ & A & $0-10$ & 10YR 6/3 & $\mathrm{cl}$ & w,c,sbk-abk & $\mathrm{gw}$ & $\begin{array}{l}\text { carb } \\
\text { frags }\end{array}$ & 53.5 & 14.5 & 6.02 & 0.62 & 6.34 & 0.34 & 0.54 & 0.77 & 0.06 & 0.08 & 17.6 \\
\hline $\mathrm{RN}-1$ & & & Bt1 & $10-19$ & $10 \mathrm{YR} 6 / 4$ & $\mathrm{c}$ & w,c,sbk-abk & $\mathrm{cw}$ & & 55.0 & 15.2 & 6.23 & 0.60 & 6.23 & 0.39 & 0.58 & 0.81 & $<0.05$ & 0.09 & 15.4 \\
\hline $\mathrm{RN}-1$ & & & Bt2 & $19-26$ & 10YR 6/4 & $\mathrm{c}$ & & aw & $\mathrm{pf}$ & 51.6 & 16.5 & 6.51 & 0.66 & 6.12 & 0.26 & 0.49 & 0.79 & $<0.05$ & 0.07 & 16.6 \\
\hline $\mathrm{RN}-1$ & & & $\mathrm{R}$ & $26+$ & & & & & & & & & & & & & & & & \\
\hline $\mathrm{RN}-2 \mathrm{~A}$ & $\sim 42$ & $\sim 220 ?$ & A & $0-12$ & $7.5 \mathrm{YR} 5 / 3$ & $\mathrm{cl}$ & $\mathrm{s}, \mathrm{f}-\mathrm{m}, \mathrm{abk}$ & $\mathrm{gw}$ & & 53.2 & 14.5 & 7.39 & 0.66 & 2.91 & 0.18 & 0.38 & 1.07 & 0.10 & 0.12 & 19.5 \\
\hline RN-2A & & & $\mathrm{AB}$ & $12-21$ & 5 YR $5 / 4$ & $\mathrm{c}$ & $\mathrm{m}, \mathrm{f}-\mathrm{m}, \mathrm{abk}$ & $\mathrm{gw}$ & wc & 54.7 & 16.7 & 8.13 & 0.71 & 1.65 & 0.16 & 0.38 & 1.08 & 0.08 & 0.12 & 17.1 \\
\hline $\mathrm{RN}-2 \mathrm{~A}$ & & & BAt & $21-29$ & $2.5 \mathrm{YR} 5 / 4$ & $\mathrm{c}$ & $\mathrm{m}, \mathrm{f}-\mathrm{m}, \mathrm{abk}$ & cs & wc & 51.3 & 20.0 & 9.41 & 0.73 & 0.95 & 0.15 & 0.40 & 1.04 & 0.06 & 0.05 & 16.5 \\
\hline $\mathrm{RN}-2 \mathrm{~A}$ & & & $\mathrm{Bt}$ & $29-40$ & $2.5 \mathrm{YR} 5 / 4$ & $\mathrm{c}$ & $\mathrm{m}, \mathrm{m}, \mathrm{abk}$ & aw & wc & 46.3 & 21.8 & 9.66 & 0.80 & 1.27 & 0.20 & 0.44 & 0.92 & 0.06 & 0.09 & 18.5 \\
\hline $\mathrm{RN}-2 \mathrm{~A}$ & & & $\mathrm{C}$ & $40-43$ & $10 \mathrm{YR} 8 / 3$ & & massive & & & 3.95 & 1.82 & 0.70 & 0.88 & 51.7 & $<0.15$ & 0.07 & 0.03 & $<0.05$ & $<0.02$ & 41.1 \\
\hline $\mathrm{RN}-2 \mathrm{~A}$ & & & $\mathrm{R}$ & $43+$ & 10YR 8/1 & & massive & & & & & & & & & & & & & \\
\hline RN-2B & $\sim 42$ & $\sim 220 ?$ & A & $0-9$ & $7.5 \mathrm{YR} 5 / 2$ & $\mathrm{c}$ & $\mathrm{s}, \mathrm{f}-\mathrm{m}, \mathrm{abk}$ & gs & & 50.2 & 15.3 & 7.09 & 0.80 & 1.52 & 0.18 & 0.42 & 0.88 & 0.12 & 0.15 & 23.0 \\
\hline $\mathrm{RN}-2 \mathrm{~B}$ & & & $\mathrm{AB}$ & $9-16$ & $7.5 \mathrm{YR} 5 / 3$ & $\mathrm{c}$ & $\mathrm{s}, \mathrm{f}-\mathrm{m}, \mathrm{abk}$ & cs & wc & 53.6 & 16.7 & 7.79 & 0.81 & 1.23 & 0.18 & 0.43 & 0.95 & 0.08 & 0.12 & 18.5 \\
\hline $\mathrm{RN}-2 \mathrm{~B}$ & & & BAt & $16-25$ & 5 YR $5 / 4$ & $\mathrm{c}$ & $\mathrm{s}, \mathrm{f}-\mathrm{c}, \mathrm{abk}$ & cs & wc & 53.0 & 18.4 & 8.82 & 0.87 & 1.26 & 0.15 & 0.45 & 0.96 & 0.06 & 0.05 & 16.2 \\
\hline $\mathrm{RN}-2 \mathrm{~B}$ & & & $\mathrm{Bt}$ & $25-37$ & 5 YR 5/4 & $\mathrm{c}$ & $\mathrm{m}, \mathrm{c}, \mathrm{abk}$ & $\mathrm{cw}$ & wc & 51.8 & 17.9 & 8.75 & 0.83 & 2.76 & 0.25 & 0.44 & 0.92 & 0.05 & 0.04 & 16.5 \\
\hline RN-2B & & & $\mathrm{C}$ & $37-41$ & $7.5 \mathrm{YR} 7 / 3$ & & massive & $\mathrm{ci}$ & & 15.7 & 6.72 & 2.92 & 0.91 & 38.2 & $<0.15$ & 0.19 & 0.24 & 0.07 & $<0.02$ & 35.4 \\
\hline RN-2B & & & $\mathrm{R}$ & 41 & $10 \mathrm{YR} 8 / 1$ & & massive & & & 1.57 & 0.44 & 0.12 & 0.79 & 54.6 & $<0.15$ & 0.04 & $<0.02$ & $<0.05$ & $<0.02$ & 42.0 \\
\hline $\mathrm{RN}-2 \mathrm{~B}$ & & & $\mathrm{R}$ & $>41$ & & & massive & & & 1.99 & 0.40 & 0.13 & 0.62 & 54.8 & $<0.15$ & 0.04 & $<0.02$ & $<0.05$ & $<0.02$ & 43.0 \\
\hline $\mathrm{RN}-3$ & $\sim 64$ & $\sim 330 ?$ & A & $0-4$ & $10 \mathrm{YR} 4 / 2$ & $\mathrm{c}$ & $\mathrm{m}, \mathrm{f}-\mathrm{m}, \mathrm{abk}$ & ci & $\mathrm{c}, \mathrm{k}$ & 56.4 & 14.2 & 6.33 & 1.00 & 1.35 & 0.15 & 0.22 & 0.83 & 0.07 & 0.36 & 19.1 \\
\hline $\mathrm{RN}-3$ & & & BAt & $4-15$ & $7.5 \mathrm{YR} 5 / 4$ & $\mathrm{c}$ & $\mathrm{m}, \mathrm{m}-\mathrm{c}, \mathrm{abk}$ & cs & $\mathrm{ss}, \mathrm{c}, \mathrm{wc}$ & 53.6 & 15.6 & 8.21 & 1.11 & 1.29 & $<0.15$ & 0.25 & 0.85 & 0.05 & 0.05 & 19.0 \\
\hline $\mathrm{RN}-3$ & & & $\mathrm{Bt} 1$ & $15-36$ & $7.5 \mathrm{YR} 6 / 6$ & $\mathrm{c}$ & $\mathrm{m}, \mathrm{c}, \mathrm{abk}$ & $\mathrm{gw}$ & $\mathrm{ss}, \mathrm{c}, \mathrm{wc}$ & 53.6 & 17.0 & 8.87 & 1.16 & 1.20 & $<0.15$ & 0.27 & 0.88 & $<0.05$ & $<0.02$ & 16.7 \\
\hline $\mathrm{RN}-3$ & & & $\mathrm{Bt} 2$ & $36-51$ & 7.5 YR $6 / 6$ & $\mathrm{c}$ & $\mathrm{w}, \mathrm{c}, \mathrm{abk}$ & $\mathrm{gw}$ & ss,c & 53.8 & 17.8 & 8.10 & 1.18 & 1.25 & 0.20 & 0.31 & 0.83 & $<0.05$ & $<0.02$ & 16.7 \\
\hline $\mathrm{RN}-3$ & & & $\mathrm{Bt} 3$ & $51-64$ & 7.5 YR $6 / 4$ & $\mathrm{c}$ & $\mathrm{w}, \mathrm{c}, \mathrm{abk}$ & $\mathrm{cw}$ & $\mathrm{pf}, \mathrm{c}$ & 49.1 & 17.2 & 7.43 & 1.33 & 2.97 & $<0.15$ & 0.30 & 0.73 & $<0.05$ & 0.20 & 20.1 \\
\hline RN-3 & & & Bt4 & $64-86$ & $10 \mathrm{YR} 7 / 3$ & $\mathrm{cl}$ & $\mathrm{w}, \mathrm{m}-\mathrm{c}, \mathrm{sbk}$ & cs & cf,c,carb & 20.0 & 7.98 & 3.23 & 1.14 & 33.3 & 0.16 & 0.17 & 0.28 & 0.06 & $<0.02$ & 34.0 \\
\hline $\mathrm{RN}-3$ & & & $\mathrm{C}$ & $86+$ & 10YR $8 / 2$ & & massive & & & 2.61 & 0.91 & 0.35 & 0.72 & 53.1 & $<0.15$ & 0.04 & $<0.02$ & $<0.05$ & $<0.02$ & 42.1 \\
\hline \multicolumn{21}{|c|}{ Oracabessa area } \\
\hline OR-4A & $\sim 152$ & $>780$ & A & $0-26$ & $10 \mathrm{R} 4 / 4$ & $\mathrm{c}$ & $\mathrm{m}, \mathrm{f}-\mathrm{m}, \mathrm{sbk}$ & $\mathrm{cw}$ & & 24.2 & 34.1 & 16.6 & 0.66 & 0.35 & $<0.15$ & 0.26 & 2.02 & 0.16 & 0.35 & 21.3 \\
\hline OR-4A & & & Bt1 & $26-70$ & $10 \mathrm{R} 4 / 6$ & $\mathrm{c}$ & $\mathrm{s}, \mathrm{m}-\mathrm{c}, \mathrm{sbk}$ & gs & $\mathrm{cf}$ & 25.8 & 36.8 & 17.2 & 0.67 & 0.23 & 0.29 & 0.26 & 1.97 & 0.13 & 0.26 & 16.0 \\
\hline OR-4A & & & $\mathrm{Bt} 2$ & $70-105$ & $10 \mathrm{R} 4 / 6$ & $\mathrm{c}$ & w,m-c,sbk & & cf & 26.1 & 37.2 & 17.4 & 0.67 & 0.22 & $<0.15$ & 0.27 & 1.97 & 0.11 & 0.19 & 15.6 \\
\hline OR-4A & & & $\mathrm{Bt} 2$ & $105-140$ & $10 \mathrm{R} 4 / 6$ & $\mathrm{c}$ & & & cf & 28.7 & 35.6 & 17.1 & 0.70 & 0.23 & $<0.15$ & 0.29 & 1.79 & 0.08 & 0.07 & 15.0 \\
\hline OR-4B & $\sim 152$ & $>780$ & A & $0-25$ & $10 \mathrm{R} 4 / 2$ & $\mathrm{c}$ & $\mathrm{s}, \mathrm{f}, \mathrm{gr}$ & cs & $\mathrm{sl}$ & 19.4 & 34.5 & 17.5 & 0.82 & 1.18 & $<0.15$ & 0.51 & 1.73 & 0.24 & 0.89 & 23.4 \\
\hline OR-4B & & & $\mathrm{Bt}$ & $25-33$ & $10 \mathrm{R} 4 / 3$ & $\mathrm{c}$ & $\mathrm{s}, \mathrm{f}-\mathrm{m}, \mathrm{sbk}$ & & of & 19.9 & 36.7 & 18.5 & 0.82 & 0.86 & $<0.15$ & 0.52 & 1.81 & 0.22 & 0.89 & 19.8 \\
\hline OR-4B & & & $\mathrm{Bt}$ & $33-42$ & $10 \mathrm{R} 4 / 4$ & $\mathrm{c}$ & $\mathrm{s}, \mathrm{f}-\mathrm{m}, \mathrm{sbk}$ & aw & $\mathrm{cf}$ & 20.1 & 38.0 & 19.4 & 0.81 & 0.75 & $<0.15$ & 0.53 & 1.88 & 0.20 & 0.86 & 17.7 \\
\hline OR-4B & & & $\mathrm{R}$ & $42+$ & & & massive & & & & & & & & & & & & & \\
\hline
\end{tabular}

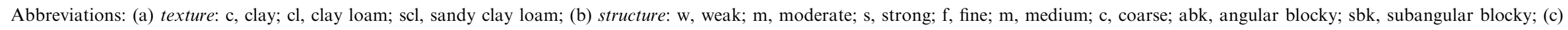

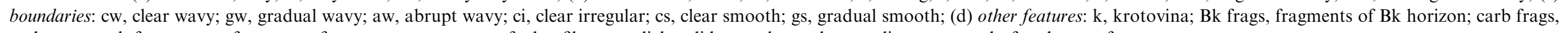
carbonate rock fragments; pf, pressure faces; wc, worm casts; cf, clay films; ss, slickenslides; c, clasts; sl, stone line composed of carbonate fragments. 
B horizons, clayey textures, and moderate-to-strong angular blocky structures. Profile RN-3, still older, has an even thicker profile $(86 \mathrm{~cm})$, although the B horizon is not as red. In addition, the B horizon has only weak-tomoderate angular blocky structure. We note, however, that at the time of description, this profile was moister than either $\mathrm{RN}-2 \mathrm{~A}$ or $\mathrm{RN}-2 \mathrm{~B}$, which may explain the lower grade of structure. Profiles OR-4A and OR-4B, on the oldest terrace, show a much more developed soil morphology than any of the other soils. Profile OR-4B is relatively thin $(\sim 42 \mathrm{~cm})$, so we suspect it has been eroded, because OR-4A, just a short distance away, has a thickness of more than $140 \mathrm{~cm}$. Both soils have 10R hues, very clayey B horizons, and mostly strong, subangular blocky structure. Profile OR-4B has a stone line composed of limestone fragments in its upper part (Fig. 7). Stone lines have been described from other tropical localities and concepts on their origin are discussed in Johnson (1993).

On the reef exposed near White River Bay, soils (WR-A and WR-B) on the $\sim 125,000$-yr-old Falmouth Formation show a degree of development intermediate between $\mathrm{RN}-1$ $(\sim 125,000 \mathrm{yr})$ and $\mathrm{RN}-2 \mathrm{~A} / \mathrm{RN}-2 \mathrm{~B}(\sim 220,000 \mathrm{yr})$ in the Rio Nuevo area. These soils have moderate $(40-45 \mathrm{~cm})$ profile thicknesses, B horizons with mostly clay loam or sandy clay loam textures, $5 \mathrm{YR}$ or 7.5YR hues, and moderate-toweak angular or subangular blocky structure. WR-B, which developed on carbonate sands of the lagoonal facies of this reef, has a cemented $\mathrm{Bk}$ horizon below the $\mathrm{Bt}$ horizon.

\subsection{Clay mineralogy}

Because all of the soils we studied have particle size distributions dominated by clay, we conducted detailed clay mineralogical analyses to see if there are changes with relative age. The A horizon of $\mathrm{RN}-1$, the youngest soil with the weakest profile development, has strong peaks at $7.13 \AA$ $\left(12.4^{\circ} 2 \theta\right)$ and $3.56 \AA\left(25.0^{\circ} 2 \theta\right)$. These two peaks are unaffected by glycolation, but collapse with heating to $550{ }^{\circ} \mathrm{C}$ for $2 \mathrm{~h}$, behavior that is typical for kaolinite. The $7.13 \AA\left(12.4^{\circ} 2 \theta\right)$ peak has a gradual drop-off on the lowangle side and a sharp drop-off on the high-angle side, whereas the $3.56 \AA\left(25.0^{\circ} 2 \theta\right)$ peak has a sharp drop-off on the low angle side and a gradual drop-off on the high-angle side (Fig. 8). The asymmetry of the two kaolinite peaks may indicate that this mineral is poorly crystallized or interstratified. $\mathrm{RN}-1$ also has a strong peak at $3.34 \AA$ $\left(26.6^{\circ} 2 \theta\right)$ which is unaffected by glycolation and heating, indicating quartz. A minor peak at $9.9 \AA\left(8.9^{\circ} 2 \theta\right)$, also unaffected by glycolation and heat treatment, indicates possible minor amounts of mica, but the high background on this sample makes this interpretation uncertain. Profile WR-A, also young, but with better profile development, has kaolinite peaks similar in form and intensity to those of profile $\mathrm{RN}-1$, consistent with what we infer to be similar ages (Fig. 8). However, both the A and $\mathrm{B}$ horizons of WR-A lack quartz. In addition, both horizons have a small peak at $4.85 \AA\left(18.3^{\circ} 2 \theta\right)$, although the peak in the $\mathrm{B}$ horizon is less distinct. This mineral may be gibbsite.

Both the A and B horizons of RN-2A, older than RN-1 and WR-A, show very strong and more symmetrical kaolinite peaks as well as strong quartz peaks (Fig. 8). In addition, however, both horizons, when air-dry, show broad peaks at $12.8 \AA\left(6.9^{\circ} 2 \theta\right)$, with a gradual drop-off to the high-angle side. In the $\mathrm{A}$ horizon, this peak forms a broad rise from about $14.7 \AA\left(6.0^{\circ} 2 \theta\right)$ to $10 \AA\left(8.8^{\circ} 2 \theta\right)$ and diminishes to a small peak at $\sim 9.6 \AA\left(9.2^{\circ} 2 \theta\right)$ with heating. In the $\mathrm{B}$ horizon, the broad $12.8 \AA\left(6.9^{\circ} 2 \theta\right)$ peak shifts to an indistinct shoulder between about $17 \AA\left(5.2^{\circ} 2 \theta\right)$ and $11 \AA\left(8.0^{\circ} 2 \theta\right)$ when glycolated; with heating, it forms a broad rise between $14.7 \AA\left(6.0^{\circ} 2 \theta\right)$ and $9.8 \AA\left(9.0^{\circ} 2 \theta\right)$. It is difficult to interpret these patterns, but one possibility is that they represent some kind of a mixed-layer, micachlorite species.

In the A horizon of profile RN-3, still older, there are very symmetrical and prominent kaolinite and quartz peaks. In addition, however, the A horizon of this soil shows a very strong peak at $13.4-12.3 \AA\left(6.6-7.2^{\circ} 2 \theta\right)$ that shifts to a more symmetrical position of $14.2 \AA\left(6.2^{\circ} 2 \theta\right)$ upon glycolation, and collapses to $9.9 \AA\left(8.9^{\circ} 2 \theta\right)$ with heat treatment. We interpret this mineral to be chlorite. In the B horizon, kaolinite and quartz are also present, but the most abundant mineral has a broad $17-12 \AA\left(5.2-7.3^{\circ} 2 \theta\right)$ peak when air dry and glycolated and collapses to about $9.9 \AA$ $\left(8.9^{\circ} 2 \theta\right)$ upon heating. This behavior suggests possible mixed-layer smectite-chlorite. The existence of smectite is supported by the observation that most of the B horizon of this soil exhibits slickensides.

In the oldest soil studied, OR-4A, a very different mineralogy appears (Fig. 9). In both the A and B horizons of this soil, very strong and symmetrical kaolinite peaks are present. In addition, however, air-dry and glycolated patterns show an even stronger peak at $6.06 \AA\left(14.6^{\circ} 2 \theta\right)$. This peak, like the kaolinite peaks, disappears with $550^{\circ} \mathrm{C}$ heat treatment. This represents boehmite, not apparent in any of the younger soils. A very small peak is present at $14 \AA\left(6.3^{\circ} 2 \theta\right)$ in air-dry and glycolated treatments; this peak disappears after heat treatment, suggesting the presence of vermiculite or possibly low-temperature chlorite.

Overall, the soils show changes in clay mineralogy that are a function of our hypothesized ages of host deposits. All soils have kaolinite and quartz, but kaolinite peaks are sharper and more symmetrical in older soils. In the oldest soils, kaolinite is best developed of all, and in addition, boehmite is present. The sequence shows a progressively greater amount of chemical weathering with simpler clays evolving over time.

\subsection{Major element geochemistry}

Major element geochemistry gives considerable insight into soil genesis and the nature of the carbonate substrates 


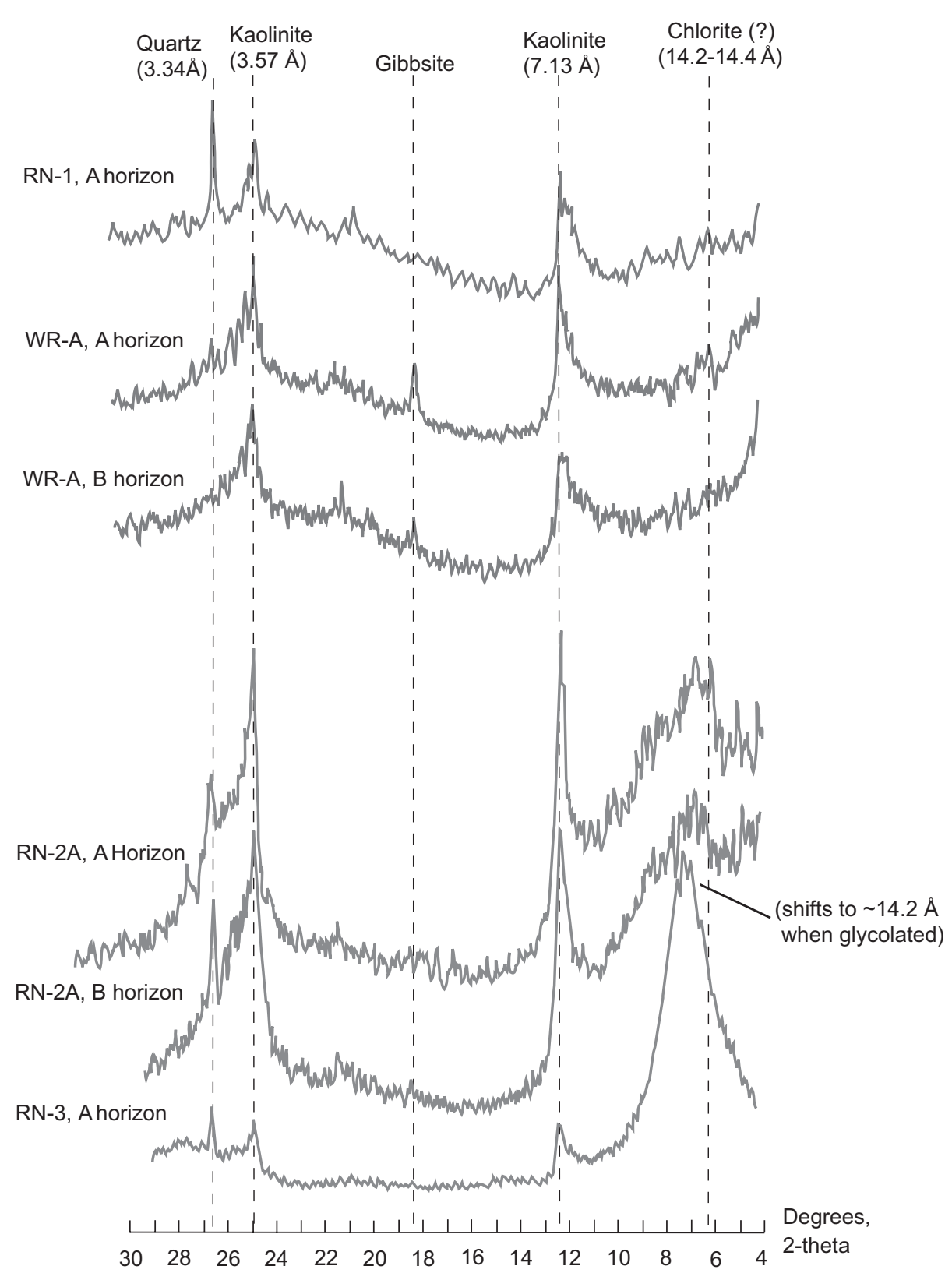

Fig. 8. Selected X-ray diffractograms (air-dry samples) of the soils studied on younger reefs.

on the north coast of Jamaica (Table 1). For the substrates under the soils, if we assume that all or most of the $\mathrm{CaO}$ is in carbonate and that loss on ignition (LOI) primarily represents $\mathrm{CO}_{2}$ loss from carbonate, then $\mathrm{CaO}+\mathrm{LOI}$ is a reasonable estimate of calcium carbonate content. Such estimates do not apply to soils such as OR-4A and OR-4B, which have high LOI and low $\mathrm{CaO}$, indicating that most of the LOI is from organic matter. However, for the deepest $\mathrm{C}$ horizons (weathered carbonate rock) and underlying carbonate rock (" $\mathrm{R}$ " horizons in Table 1) in profiles WR-B, RN-2A, $\mathrm{RN}-2 \mathrm{~B}$, and $\mathrm{RN}-3, \mathrm{CaO}+\mathrm{LOI}$ gives approximate measures of carbonate substrate purity. Carbonate contents using this method range, for six samples, from $93 \%$ to
$98 \%$. This indicates, as reported by other workers summarized earlier, that soil formation by residual accumulation of insoluble residues, if valid, would be an extremely slow process.

Major element concentrations show that Jamaican soils are highly weathered, consistent with the clay mineralogy. Concentrations of elements that are found in primary minerals are extremely low (Table 1). For example, $\mathrm{K}_{2} \mathrm{O}$ is found mainly in $\mathrm{K}$-feldspar and mica. Concentrations of $\mathrm{K}_{2} \mathrm{O}$ range from $0.2 \%$ to $0.5 \%$, indicating very little, if any $\mathrm{K}$-feldspar or mica in these soils. Concentrations of $\mathrm{Na}_{2} \mathrm{O}$ in Jamaican soils are also extremely low, below detection limits of $0.15 \%$ in many horizons. Because $\mathrm{Na}_{2} \mathrm{O}$ is found primarily in plagioclase (and to a lesser extent in 


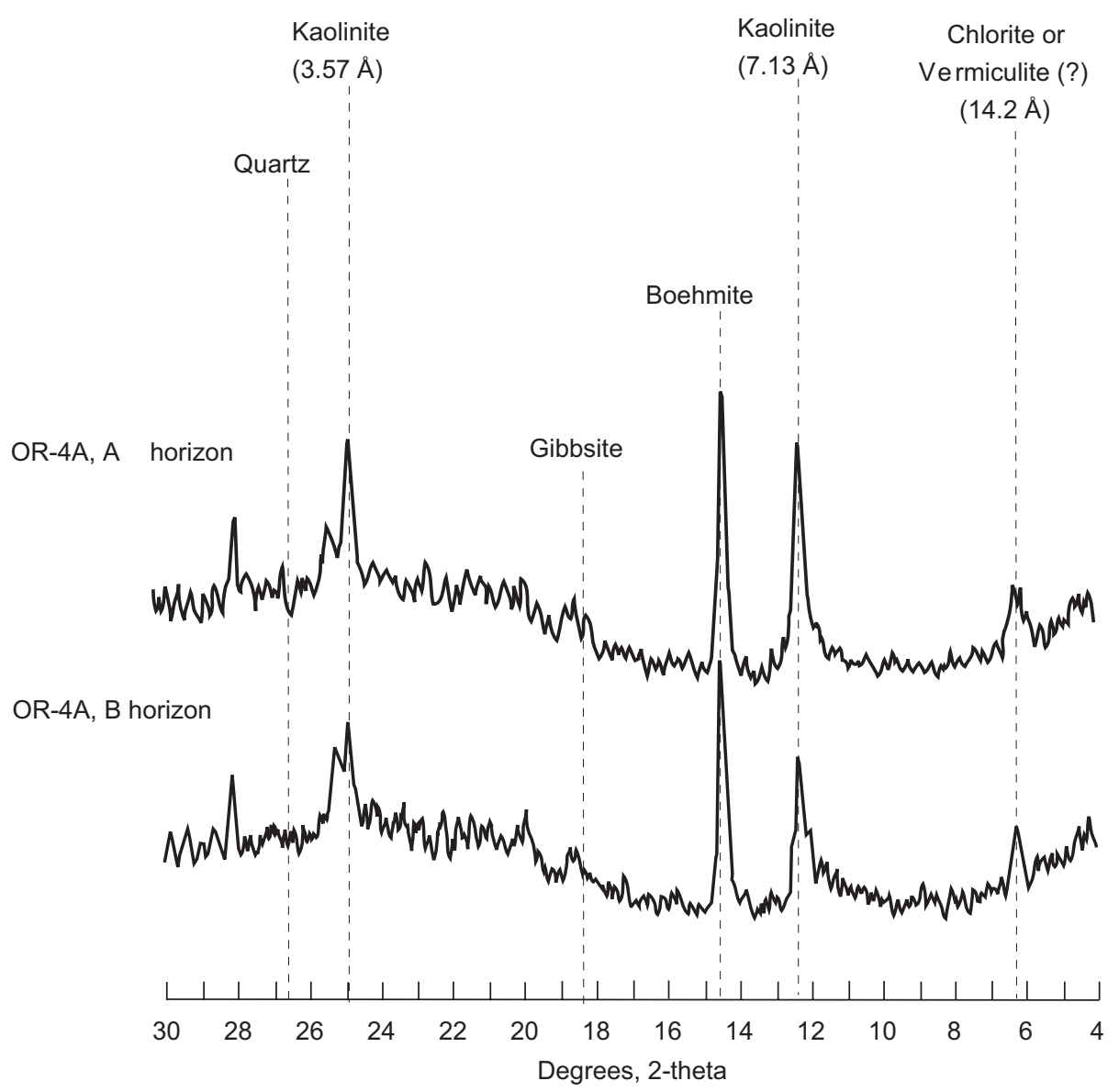

Fig. 9. Selected X-ray diffractograms (air-dry samples) of the soils studied on older reefs.

hornblende), low values of this element indicate little or no amounts of these minerals.

A commonly used measure of degree of chemical weathering in soils is the $\mathrm{SiO}_{2} / \mathrm{Al}_{2} \mathrm{O}_{3}$ value (Birkeland, 1999). A clay mineralogy dominated by kaolinite, or kaolinite and boehmite (OR-4A), indicates considerable depletion of $\mathrm{SiO}_{2}$ relative to mostly immobile $\mathrm{Al}_{2} \mathrm{O}_{3}$. In the Jamaican soils estimated to be of middle-to-late Quaternary age (WR-A, B, RN-1, 2A, $2 \mathrm{~B}, 3), \mathrm{SiO}_{2} / \mathrm{Al}_{2} \mathrm{O}_{3}$ ranges from 3.97 to 1.83 in the $\mathrm{A}$ and upper $\mathrm{B}$ horizons. In contrast, in the early Quaternary soils (OR-4A and OR-4B), $\mathrm{SiO}_{2} / \mathrm{Al}_{2} \mathrm{O}_{3}$ values are $0.81-0.53$, reflecting the more Al-rich mineralogy. The $\mathrm{SiO}_{2} / \mathrm{Al}_{2} \mathrm{O}_{3}$ values for the younger soils are comparable to those for soils on middle-to-late Quaternary-age reef terraces of Barbados (Muhs, 2001). The older soils on Jamaica (OR-4A and OR-4B) have $\mathrm{SiO}_{2} / \mathrm{Al}_{2} \mathrm{O}_{3}$ values similar to those of soils on relatively pure Quaternary carbonate eolianites on the Bahamas (Foos, 1991) and Bermuda (Herwitz and Muhs, 1995).

In typically red or reddish-brown Jamaican terra rossa soils, dominant colors reflect the total $\mathrm{Fe}_{2} \mathrm{O}_{3}$ content (Table 1). Although our data are for total $\mathrm{Fe}_{2} \mathrm{O}_{3}$, both that in primary minerals and that in secondary products, such as hematite and goethite, soils with redder colors also have higher total $\mathrm{Fe}_{2} \mathrm{O}_{3}$ content. For example, profile RN-1 has
$10 \mathrm{YR}$ hues and $\mathrm{Fe}_{2} \mathrm{O}_{3}$ contents of $\sim 6 \%$ in all horizons. Profile RN-2A has redder, 2.5YR hues in its $\mathrm{B}$ horizon and $\mathrm{Fe}_{2} \mathrm{O}_{3}$ contents of $\sim 9 \%$. Profiles OR-4A and OR-4B have very red, 10R hues, and $\mathrm{Fe}_{2} \mathrm{O}_{3}$ contents of $\sim 16-19 \%$. Thus, we interpret these data to mean that much of the $\mathrm{Fe}_{2} \mathrm{O}_{3}$ content reflects the relative abundance of hematite, the mineral that provides a red pigment to soils. Scholten and Andriesse (1986), studying soils on the Tertiary White Limestone of Jamaica, also report that a majority of total $\mathrm{Fe}_{2} \mathrm{O}_{3}$ is found in secondary products.

\subsection{Trace element geochemistry}

For provenance studies, we utilized only those elements that are considered, on the basis of high ionic potential, to be immobile in low-temperature, near-surface environments. The suite of elements chosen includes $\mathrm{Th}, \mathrm{Cr}, \mathrm{Sc}$, $\mathrm{Zr}$, and $\mathrm{Y}$ as well as the REE, La (the lightest REE) to $\mathrm{Lu}$ (the heaviest REE). The most likely host minerals for $\mathrm{Cr}$ and Sc are micas, amphiboles and clay minerals. Th can be hosted by micas, amphiboles, zircon, sphene and clay minerals. $\mathrm{Zr}$ is found almost exclusively in zircon. The REE and $\mathrm{Y}$ can be hosted by micas, chlorite, clay minerals, amphiboles, sphene, zircon, apatite and, to some degree, feldspars. 
REE concentrations are typically normalized to chondritic meteorite compositions and we follow this protocol. In the discussions of REE patterns that follow, the terms "enriched" and "depleted" are used in descriptions and interpretations. Because all samples analyzed have higher concentrations of REE compared to chondrites, these terms refer to relative abundances of different parts of the REE suite compared to other parts, e.g., light REE compared to heavy REE. Another parameter for chondrite-normalized REE is the $\mathrm{Eu}$ anomaly, which is the chondrite-normalized concentration of Eu relative to Sm and Gd. The degree of Eu anomaly can be quantified by the $\mathrm{Eu} / \mathrm{Eu}^{*}$ value, where "Eu" is the chondrite-normalized Eu concentration $\left(\mathrm{Eu}_{\mathrm{N}}\right)$, and "Eu*" is $\left(\mathrm{Sm}_{\mathrm{N}} \times \mathrm{Gd}_{\mathrm{N}}\right)^{0.5}$. Values for $\mathrm{Eu} / \mathrm{Eu}^{*}$ that are less than 1.0 are termed negative Eu anomalies; values greater than 1.0 are positive $\mathrm{Eu}$ anomalies.

There is a REE pattern that is typical for rocks from the upper continental crust (Taylor and McLennan, 1985, 1995; McLennan, 1989) or mixed sediments derived from the upper crust, such as loess (Gallet et al., 1996, 1998; Jahn et al., 2001; Muhs and Budahn, 2006). In sediments derived from the upper continental crust, light REE are enriched, there is a negative Eu anomaly, and the heavy REE are depleted. In contrast to the upper continental crust, basalt has low overall abundances of REE, relatively "flat" curves (i.e., no light REE enrichment), and no Eu anomaly (see examples from Hawaii in Budahn and Schmitt, 1985).

Garrett et al. (2004) note that many Jamaican terra rossa soils have high concentrations of certain trace elements, including $\mathrm{Hf}, \mathrm{Th}, \mathrm{Ti}, \mathrm{Sc}, \mathrm{Cr}$, and the REE. As these investigators note, these relatively immobile elements tend to accumulate with the loss of more mobile constituents such as $\mathrm{SiO}_{2}, \mathrm{CaO}, \mathrm{MgO}, \mathrm{Na}_{2} \mathrm{O}$, and $\mathrm{K}_{2} \mathrm{O}$. Our results (Table 2) agree with their observations, and fit with current theoretical understanding of trace element mobility in soil environments (Mason and Moore, 1982; Taylor and McLennan, 1985, 1995; McLennan, 1989). We report here the concentrations of $\mathrm{Th}, \mathrm{Cr}, \mathrm{Sc}, \mathrm{Zr}, \mathrm{La}$, and $\mathrm{Y}$ as a function of estimated reef age. All of these elements show relative increases in the soils with estimated terrace age, excluding substrate-dominated horizons where concentrations are low due simply to carbonate dilution (Fig. 10). The coefficients of determination $\left(r^{2}\right.$ values) for trace element concentrations versus estimated substrate age range from $\sim 40 \%$ to $\sim 80 \%$, and all values are significant. Muhs et al. (2007a) report similar results for many of these same elements in a chronosequence of soils on reef terraces of Barbados. The results are important, because it is these elements that are useful as provenance indicators.

Soils on limestones from the northern coast of Jamaica show many of the same REE characteristics as those on Barbados, the Bahamas, and the Florida Keys (Muhs et al., 2007a). All soils are relatively enriched in light REE, have negative Eu anomalies and relatively flat heavy REE curves (Fig. 11). As discussed above, this is a typical pattern for loess and other sediments derived from the upper continental crust. Hence, we interpret Jamaican soils to have had upper continental crustal rocks as their ultimate source.

As is also the case on Barbados, some horizons of Jamaican soils show negative $\mathrm{Ce}$ anomalies. In the Rio Nuevo soil sequence, negative $\mathrm{Ce}$ anomalies are found mostly in the lowest, most carbonate-rich horizons of RN-2A, RN-2B, and RN-3 (Fig. 11), also the case with Barbados soils. Muhs et al. (2007a) show that unaltered fossil corals from Florida and the Bahamas do not have negative $\mathrm{Ce}$ anomalies inherited from sea water, but positive $\mathrm{Ce}$ anomalies. Thus, although we suspect that the cause of the negative $\mathrm{Ce}$ anomalies here (and on Barbados) may be due to the carbonate substrate, it is carbonate components other than coral that are the probable cause. Webb and Kamber (2000) show, for example, that carbonate reef microbialites have negative $\mathrm{Ce}$ anomalies, presumably inherited from the negative $\mathrm{Ce}$ anomaly found in sea water. However, Holser (1997) shows that diagenesis plays a complex, and not completely understood, role in Ce anomalies in carbonate rocks with mixtures of skeletal components.

\section{Comparison of trace element geochemistry of Jamaican soils and possible source materials}

\subsection{Ti-Zr-Y and Sc-Th-La-Zr-Ta as provenance indicators}

Pearce and Cann (1973) demonstrate that relative abundances of the high-field-strength (i.e., immobile in near-surface environments) elements $\mathrm{Ti}, \mathrm{Zr}$, and $\mathrm{Y}$, when displayed on ternary diagrams, are powerful tools for determining the origin of volcanic rocks. The same approach can be used for soils and their candidate parent materials. The abundance of other high-field-strength elements, particularly Sc, Th, $\mathrm{La}, \mathrm{Cr}$, Ta and $\mathrm{Hf}$, have been used in studies of the origin of sedimentary rocks (Bhatia and Crook, 1986; McLennan, 1989) and the sources of dust, loess, and the eolian component of deepsea sediments (Olivarez et al., 1991; Sun, 2002; Muhs and Budahn, 2006; Muhs et al., 2007a, b, Ziegler et al., 2007). Indeed, many of these elements have been crucial in reconstructing the geologic history of the continental crust itself (Taylor and McLennan, 1985).

The specific elements we use in our comparisons of Jamaican soils and possible parent materials are a function of what limited data are available. For example, we were unable to find $\mathrm{Sc}$, Th, or REE data for igneous and metamorphic rocks on Jamaica (found in the Blue Mountains and as inliers in Fig. 2). However, Jackson et al. (1989) and Jackson and Scott (2002) report Ti, Zr, and $\mathrm{Y}$ data for these rocks, which we compare to Jamaican soils we analyzed. Tephra from the Lesser Antilles island arc, African dust, and the fine-grained $(<20 \mu \mathrm{m})$ component of lower Mississippi River valley loess have all been 
Table 2

Trace element geochemistry of carbonate-hosted soils, north coast of Jamaica (all values in ppm)

\begin{tabular}{|c|c|c|c|c|c|c|c|c|c|c|c|c|c|c|c|c|c|c|c|c|c|c|c|c|c|c|}
\hline Profile\# & Inner edge elev. (m) & Estimated age (ka) & Horizon & Depth $(\mathrm{cm})$ & Cs & $\mathrm{Rb}$ & $\mathrm{Ba}$ & $\mathrm{Sr}$ & Th & $\mathrm{U}$ & $\mathrm{Ta}$ & $\mathrm{Zr}$ & $\mathrm{Hf}$ & $\mathrm{Sb}$ & Sc & $\mathrm{Cr}$ & $\mathrm{La}$ & $\mathrm{Ce}$ & $\mathrm{Nd}$ & $\mathrm{Sm}$ & $\mathrm{Eu}$ & $\mathrm{Gd}$ & $\mathrm{Tb}$ & $\mathrm{Tm}$ & $\mathrm{Yb}$ & $\mathrm{Lu}$ \\
\hline \multicolumn{27}{|c|}{ White River area } \\
\hline WR-A & $\sim 8$ & $\sim 125 ?$ & Аp & $0-13$ & 5.04 & 45.1 & 143 & 114 & 9.02 & 2.26 & 1.23 & 239 & 5.59 & 2.04 & 25.8 & 325 & 57.8 & 98.1 & 51.5 & 11.3 & 2.76 & 10.9 & 1.73 & 0.982 & 6.18 & 0.891 \\
\hline WR-A & & & $\mathrm{AB}$ & $13-25$ & 5.44 & 45.4 & 141 & & 9.19 & 2.1 & 1.23 & 288 & 5.35 & 2.14 & 27.2 & 307 & 58.9 & 93 & 51.7 & 11.4 & 2.82 & 10.6 & 1.75 & 1 & 6.3 & 0.901 \\
\hline WR-A & & & $\mathrm{Bt}$ & $25-40$ & 5.83 & 46 & 95.7 & 103 & 8.61 & 1.97 & 0.974 & 254 & 4.27 & 2.35 & 27.4 & 293 & 54 & 81.8 & 48.2 & 11.5 & 2.91 & 10.6 & 1.72 & 1.05 & 6.54 & 0.94 \\
\hline WR-A & & & $\mathrm{R}$ & $40+$ & & & & & & & & & & & & & & & & & & & & & & \\
\hline WR-B & $\sim 8$ & $\sim 125 ?$ & A & $0-10$ & 5.24 & 42.5 & 114 & & 8.13 & 1.59 & 1.1 & 211 & 4.99 & 1.95 & 24.4 & 258 & 60.3 & 87.3 & 52.2 & 11.9 & 2.9 & 11.8 & 1.83 & 1.03 & 6.18 & 0.9 \\
\hline WR-B & & & $\mathrm{AB}$ & $10-19$ & 4.36 & 31.6 & 106 & & 6.63 & 1.47 & 0.871 & 198 & 3.87 & 1.59 & 19.9 & 193 & 50.4 & 68.4 & 44.9 & 9.86 & 2.37 & 9.56 & 1.48 & 0.836 & 5.02 & 0.718 \\
\hline WR-B & & & Bt1 & $19-27$ & 2.06 & 17 & 54.1 & 81.2 & 2.84 & 0.78 & 0.385 & 78.2 & 1.57 & 0.795 & 9.2 & 92.5 & 23.2 & 27.2 & 21.6 & 4.59 & 1.11 & 4.46 & 0.679 & 0.353 & 2.2 & 0.321 \\
\hline WR-B & & & Bt2 & $27-34$ & 1.76 & 13.7 & 54.1 & 62.2 & 2.55 & 0.669 & 0.304 & 75 & 1.41 & 0.617 & 8.08 & 75.3 & 19.8 & 24.3 & 17.3 & 3.8 & 0.952 & 3.46 & 0.588 & 0.334 & 1.96 & 0.277 \\
\hline WR-B & & & Bt3 & $34-41$ & 1.28 & 9.87 & 48.3 & 61.7 & 1.95 & 0.473 & 0.242 & 54.6 & 1.05 & 0.507 & 6.15 & 54.1 & 14.8 & 18.8 & 13.8 & 2.9 & 0.724 & 2.93 & 0.429 & 0.239 & 1.46 & 0.212 \\
\hline WR-B & & & $\mathrm{Bk}$ & $41-45$ & 0.059 & & 28.5 & 97.8 & 0.078 & 0.163 & 0.021 & 3.11 & 0.051 & 0.05 & 0.3 & 3.79 & 0.69 & 0.97 & 0.7 & 0.16 & 0.04 & 0 & 0.028 & 0 & 0.073 & 0.0111 \\
\hline WR-B & & & $\mathrm{CBk}$ & $45-66$ & 0.104 & 2.64 & 36.3 & 128 & 0.168 & 0.37 & 0.083 & 7.57 & 0.183 & 0.127 & 0.79 & 12.2 & 1.71 & 2.65 & 2.05 & 0.48 & 0.111 & 0.438 & 0.065 & 0.037 & 0.221 & 0.0324 \\
\hline WR-B & & & $\mathrm{C}$ & $66+$ & 0.109 & 3.27 & 38 & 121 & 0.165 & 0.325 & 0.054 & 15.8 & 0.148 & 0.185 & 0.87 & 16.1 & 1.79 & 3 & 2.01 & 0.5 & 0.136 & 0 & 0.08 & 0.039 & 0.224 & 0.0306 \\
\hline \multicolumn{27}{|c|}{ Rio Nuevo area } \\
\hline $\mathrm{RN}-1$ & $\sim 30$ & $\sim 125 ?$ & A & $0-10$ & 1.73 & 28.7 & 160 & 162 & 4.56 & 1.67 & 0.566 & 152 & 4.53 & 0.797 & 14.1 & 97.4 & 13.6 & 26.9 & 12.8 & 3.33 & 0.748 & & 0.526 & 0.334 & 2.11 & 0.326 \\
\hline RN-1 & & & Bt1 & $10-19$ & 1.98 & 28.7 & 213 & 121 & 4.85 & 1.82 & 0.653 & 127 & 4.93 & 0.927 & 14.8 & 90.1 & 14.3 & 30.1 & 13.9 & 3.6 & 0.806 & & 0.559 & 0.368 & 2.28 & 0.352 \\
\hline RN-1 & & & Bt2 & $19-26$ & 2.04 & 30 & 145 & 166 & 5.18 & 1.81 & 0.641 & 163 & 5.19 & 0.895 & 16.9 & 74.7 & 18.2 & 35.3 & 19.9 & 4.85 & 1.19 & 4.93 & 0.748 & 0.47 & 2.96 & 0.449 \\
\hline $\mathrm{RN}-1$ & & & $\mathrm{R}$ & $26+$ & & & & & & & & & & & & & & & & & & & & & & \\
\hline $\mathrm{RN}-2 \mathrm{~A}$ & $\sim 42$ & $\sim 220 ?$ & A & $0-12$ & 3.62 & 30.9 & 82.7 & 38 & 7.58 & 2.01 & 1.03 & 270 & 6.31 & 0.867 & 18.4 & 452 & 38.6 & 72 & 35.1 & 8.44 & 1.9 & 7.76 & 1.27 & 0.775 & 4.73 & 0.692 \\
\hline $\mathrm{RN}-2 \mathrm{~A}$ & & & $\mathrm{AB}$ & $12-21$ & 4.2 & 36 & 94.4 & 32.8 & 8.52 & 1.92 & 1.12 & 278 & 6.28 & 1.03 & 21.1 & 416 & 40.6 & 82.2 & 38.9 & 8.76 & 2.06 & 8.85 & 1.37 & 0.835 & 5.13 & 0.744 \\
\hline $\mathrm{RN}-2 \mathrm{~A}$ & & & BAt & $21-29$ & 4.73 & 37.1 & 85.1 & & 8.67 & 1.85 & 1.05 & 264 & 5.65 & 1.17 & 23.2 & 379 & 29.2 & 65.4 & 28.9 & 7.65 & 1.76 & & 1.18 & 0.739 & 4.8 & 0.702 \\
\hline $\mathrm{RN}-2 \mathrm{~A}$ & & & $\mathrm{Bt}$ & $29-40$ & 5.24 & 40.7 & 85.7 & & 8.9 & 1.7 & 0.909 & 269 & 4.57 & 1.12 & 25.3 & 335 & 51.2 & 119 & 62 & 15.4 & 3.74 & 15.4 & 2.47 & 1.43 & 9.21 & 1.31 \\
\hline RN-2A & & & $\mathrm{C}$ & $40-43$ & 0.582 & 5 & 22.1 & 419 & 0.8 & 1.21 & 0.087 & & 0.333 & 0.119 & 2.42 & 28.4 & 7.81 & 6.1 & 7.18 & 1.61 & 0.369 & & 0.248 & 0.143 & 0.863 & 0.115 \\
\hline $\mathrm{RN}-2 \mathrm{~A}$ & & & $\mathrm{R}$ & $43+$ & & & & & & & & & & & & & & & & & & & & & & \\
\hline RN-2B & $\sim 42$ & $\sim 220 ?$ & A & $0-9$ & 3.97 & 35.1 & 91.3 & 30 & 8.09 & 1.86 & 1 & 233 & 5.57 & 1.02 & 20.3 & 293 & 59.8 & 90.5 & 50 & 11.9 & 2.91 & & 1.9 & 1.04 & 6.46 & 0.925 \\
\hline RN-2B & & & $\mathrm{AB}$ & $9-16$ & 4.14 & 39.4 & 117 & & 8.46 & 1.82 & 1.12 & 316 & 5.43 & 1.29 & 21.9 & 310 & 56.6 & 96.4 & 51.8 & 12.2 & 2.98 & & 1.96 & 1.12 & 6.78 & 0.981 \\
\hline RN-2B & & & BAt & $16-25$ & 4.5 & 39.5 & 54.2 & & 9.3 & 1.77 & 1.12 & 254 & 5.68 & & 24.6 & 318 & 42.8 & 89.4 & 43.6 & 10.8 & 2.61 & & 1.66 & 1.03 & 6.27 & 0.932 \\
\hline RN-2B & & & $\mathrm{Bt}$ & $25-37$ & 4.09 & 34.7 & 75.5 & 58 & 8.98 & 2.05 & 1.04 & 296 & 5.19 & 1.16 & 23.6 & 316 & 57.4 & 94.1 & 61.3 & 14.8 & 3.52 & 12.9 & 2.2 & 1.32 & 8.05 & 1.16 \\
\hline RN-2B & & & $\mathrm{C}$ & $37-41$ & 1.73 & 15.8 & 41.6 & 366 & 2.78 & 1.85 & 0.306 & 139 & 1.69 & 0.361 & 8.25 & 80.9 & 66.7 & 29 & 50.8 & 9.78 & 2.31 & 10.2 & 1.48 & 0.687 & 4.09 & 0.596 \\
\hline RN-2B & & & $\mathrm{R}$ & $41+$ & 0.09 & 1.27 & 21.7 & 448 & 0.168 & 1.31 & 0.058 & 12.7 & 0.118 & 0.063 & 0.68 & 10.8 & 2.38 & 2.48 & 2.4 & 0.55 & 0.116 & & 0.084 & 0.05 & 0.3 & 0.0415 \\
\hline RN-2B & & & $\mathrm{R}$ & $41++$ & & & & & & & & & & & & & & & & & & & & & & \\
\hline $\mathrm{RN}-3$ & $\sim 64$ & $\sim 330 ?$ & A & $0-4$ & 3.69 & 23.3 & 93.7 & & 6.65 & 1.69 & 0.84 & 212 & 4.59 & 0.999 & 16.9 & 211 & 41.3 & 80.6 & 35.8 & 7.44 & 1.71 & 6.34 & 1.13 & 0.595 & 3.77 & 0.558 \\
\hline RN-3 & & & BAt & $4-15$ & 4.33 & 26.7 & 62.1 & & 7.04 & 1.55 & 0.828 & 140 & 4.58 & 1.32 & 19.9 & 223 & 24.2 & 32.3 & 20 & 4.26 & 0.904 & 3.42 & 0.611 & & 2.32 & 0.362 \\
\hline RN-3 & & & Bt1 & $15-36$ & 4.38 & 28.6 & 48.1 & & 7.37 & 1.4 & 0.865 & 133 & 4.27 & 1.35 & 21.6 & 208 & 21.1 & 24.1 & 18.6 & 4.09 & 0.913 & 3.41 & 0.556 & 0.362 & 2.34 & 0.362 \\
\hline RN-3 & & & Bt2 & $36-51$ & 4.2 & 26.3 & 57.6 & 33.6 & 7 & 1.52 & 0.907 & 206 & 4.31 & 1.4 & 20.2 & 184 & 25.5 & 34.1 & 25.6 & 6.14 & 1.4 & 5.26 & 0.862 & 0.536 & 3.43 & 0.522 \\
\hline RN-3 & & & $\mathrm{Bt} 3$ & $51-64$ & 4.26 & 32.4 & 44.1 & & 6.13 & 1.47 & 0.841 & 579 & 3.78 & 1.34 & 20.2 & 174 & 88.5 & 246 & 154 & 43.3 & 11 & 43.5 & 7.14 & 3.87 & 23.7 & 3.38 \\
\hline RN-3 & & & Bt4 & $64-86$ & 1.82 & 13.7 & 52.9 & 564 & 2.51 & 1.18 & 0.264 & 246 & 1.41 & 0.694 & 9.13 & 72.5 & 113 & 35.6 & 99.8 & 20.9 & 4.73 & 19.8 & 3.03 & 1.27 & 7.49 & 1.07 \\
\hline $\mathrm{RN}-3$ & & & $\mathrm{C}$ & $86+$ & 0.227 & 1 & 27.3 & 580 & 0.291 & 0.672 & 0.029 & 14.1 & 0.195 & 0.189 & 1.11 & 11.6 & 3.96 & 2.88 & 4.26 & 0.96 & 0.235 & 0.881 & 0.145 & 0.079 & 0.483 & 0.0683 \\
\hline \multicolumn{27}{|c|}{ Oracabessa area } \\
\hline OR-4A & $\sim 152$ & $>780$ & A & $0-26$ & 9.17 & 27.8 & 71.1 & & 18 & 4.31 & 2.13 & 460 & 8.92 & 2.93 & 44.7 & 588 & 98.8 & 178 & 96.7 & 21.3 & 5.3 & 21.2 & 3.22 & 1.72 & 10.1 & 1.43 \\
\hline OR-4A & & & Bt1 & $26-70$ & 8.74 & 25.3 & 75.6 & & 18.8 & 3.95 & 2.14 & 494 & 8.57 & 2.29 & 46.6 & 595 & 96.4 & 174 & 96.8 & 21.1 & 5.2 & 20.8 & 3.26 & 1.68 & 10.1 & 1.44 \\
\hline OR-4A & & & $\mathrm{Bt} 2$ & $70-105$ & 8.77 & 28.3 & 71.9 & & 18.2 & 4.01 & 1.99 & 456 & 8.26 & 2.31 & 46.2 & 610 & 84.2 & 178 & 89.9 & 20.5 & 5.06 & 20.2 & 3.14 & 1.68 & 9.88 & 1.43 \\
\hline OR-4A & & & Bt2 & $105-140$ & 7.7 & 36 & 74.2 & & 17.8 & 4.43 & 1.89 & 293 & 7.68 & 2.43 & 45.4 & 731 & 42 & 144 & 38.1 & 8.98 & 2.1 & 7.31 & 1.36 & 1.27 & 6.72 & 0.967 \\
\hline OR-4B & $\sim 152$ & $>780$ & A & $0-25$ & 22.3 & 66.5 & 119 & & 18.8 & 3.15 & 2.15 & 489 & 7.74 & 2.55 & 43.9 & 579 & 144 & 169 & 118 & 24.2 & 5.79 & 0 & 4.01 & 1.83 & 10.5 & 1.51 \\
\hline OR-4B & & & $\mathrm{Bt}$ & $25-33$ & 22.2 & 69.5 & 150 & 84.4 & 19 & 3.41 & 2.21 & 521 & 7.79 & 2.52 & 44.9 & 579 & 148 & 172 & 113 & 24.8 & 6.13 & 26.4 & 4.11 & 1.84 & 11 & 1.55 \\
\hline OR-4B & & & $\mathrm{Bt}$ & $33-42$ & 23.2 & 70.5 & 170 & & 20.8 & 3.16 & 2.06 & 543 & 8.57 & 2.89 & 49 & 603 & 161 & 165 & 123 & 26.8 & 6.56 & 28.5 & 4.4 & 2.03 & 12.1 & 1.65 \\
\hline OR-4B & & & $\mathrm{R}$ & $42+$ & & & & & & & & & & & & & & & & & & & & & & \\
\hline
\end{tabular}



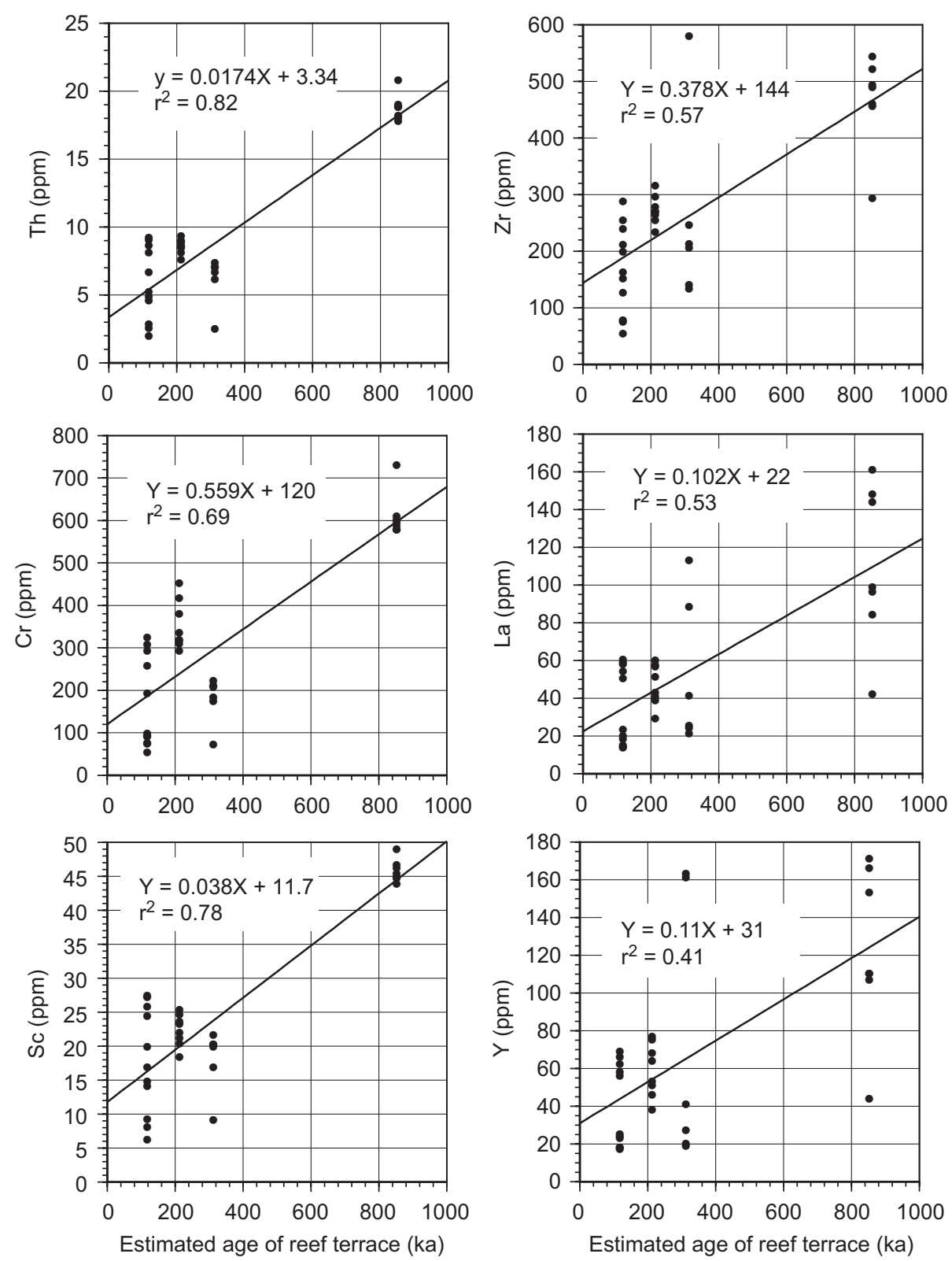

Fig. 10. Trace element concentrations of soils in the Rio Nuevo-Oracabessa chronosequence shown as a function of estimated reef-terrace age.

analyzed for Sc, Th, Zr, Ta, and the REE contents by Muhs et al. (2007a) and we use those data for comparison here. For tephra from Central American volcanoes, we use trace element data of Drexler et al. (1980) and Clift et al. (2005).

\subsubsection{Local non-carbonate rocks as parent materials evaluated by $\mathrm{Ti}-\mathrm{Zr}-\mathrm{Y}$}

Cretaceous igneous rocks in the Blue Mountains, in the Wagwater Belt, and in the "inliers" in the central part of Jamaica (Fig. 2) could conceivably add sediment to lower carbonate surfaces such as those in our study area. Erosion of these rocks and fluvial or colluvial transport of the eroded sediment onto an emergent reef is obviously one mechanism. Another could be fluvial transport to the insular shelf on the north coast of Jamaica during an interglacial period. During a subsequent glacial period, with sea-level lowering, such sediments could be deflated by wind and transported back onto the emergent reef surfaces by northeasterly trade winds. Either process could produce a veneer of non-carbonate sediment on top of an emergent carbonate reef terrace and this non-carbonate sediment could serve as the soil parent material for the A and B horizons.

Using $\mathrm{Ti}, \mathrm{Zr}$, and $\mathrm{Y}$ data for Cretaceous rocks on Jamaica (Fig. 2) reported by Jackson et al. (1989) and Jackson and Scott (2002), we note that there is little compositional overlap with Jamaican soils (Fig. 12). Although some of these rocks have compositional similarities with one another, none has significant overlap with Jamaican soils. A few soils fall within the field occupied by the Blue Mountains plutonic rocks and the Central Inlier 
a

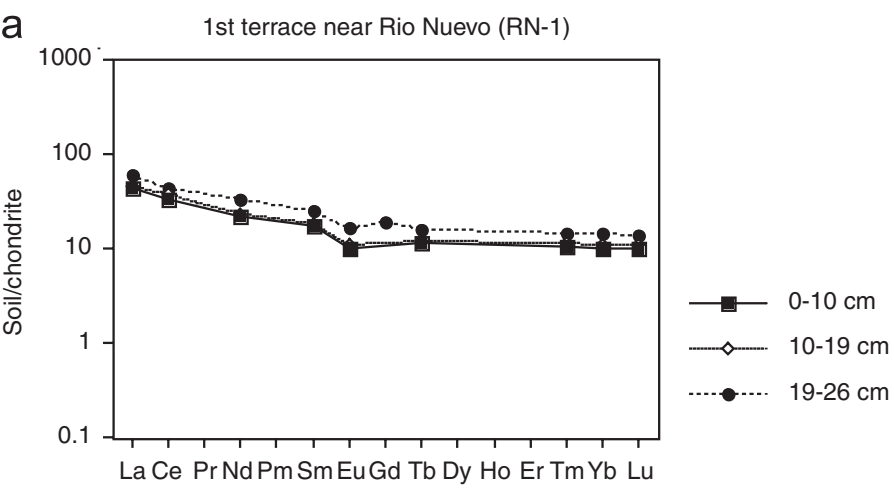

C

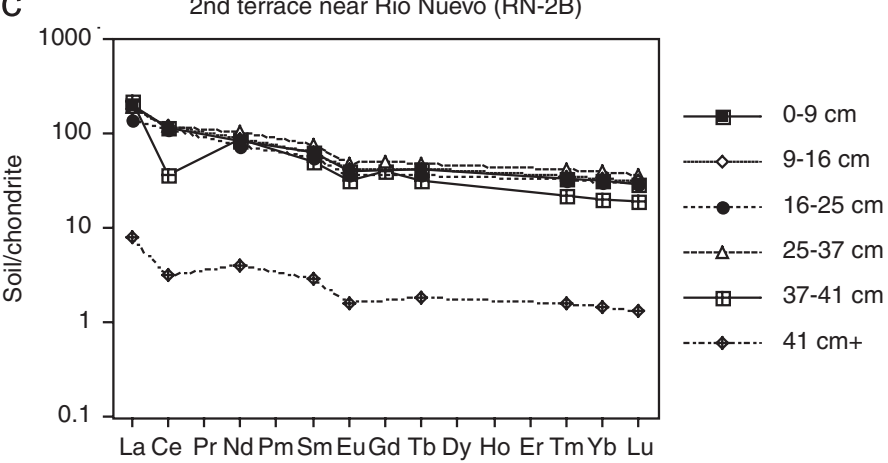

b

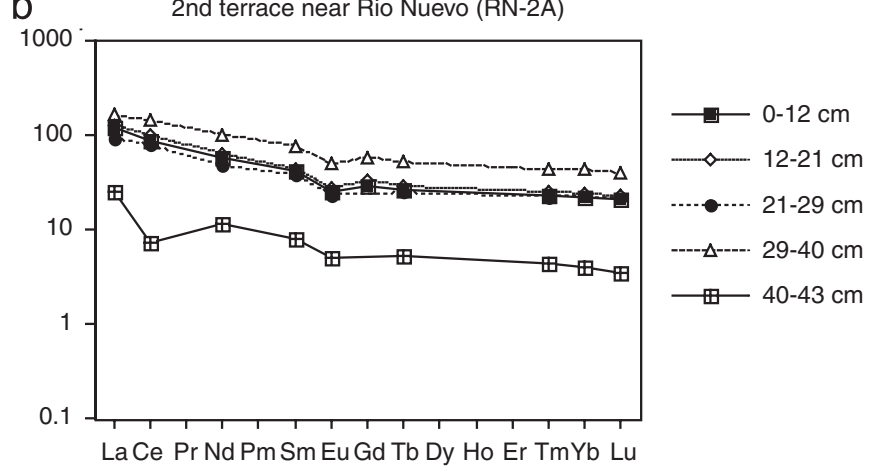

d

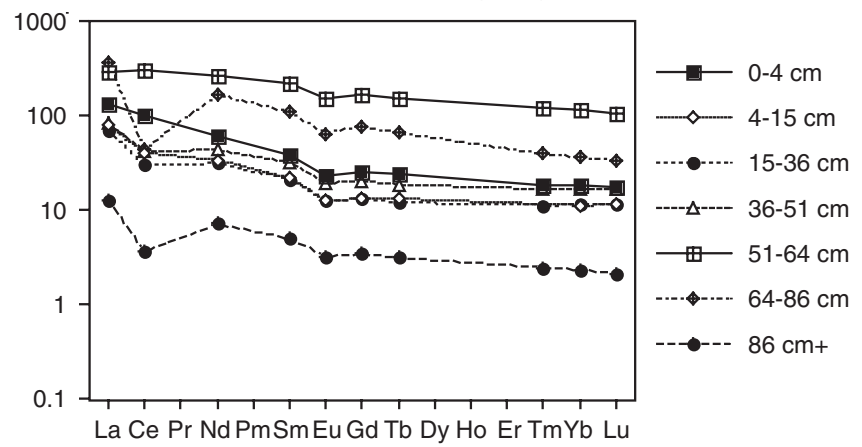

Fig. 11. Chondrite-normalized REE plots of soils in the Rio Nuevo chronosequence. (a) 1st terrace near Rio Nuevo (RN-1), (b) 2nd terrace near Rio Nuevo (RN-2A), (c) 2nd terrace near Rio Nuevo (RN-2B), (d) 3rd terrace near Rio Nuevo (RN-3).

volcanic rocks, so it is possible that some soils have had some influence from local bedrock-derived sediments. Overall, however, we interpret these data to indicate little input from local igneous rocks to the limestone-hosted soils.

\subsubsection{African and North American dust and tephra evaluated by $\mathrm{Sc}-\mathrm{Th}-\mathrm{La}-\mathrm{Zr}-\mathrm{Ta}-\mathrm{Cr}-\mathrm{Nd}$}

The use of Sc-Th-La ternary diagrams has a long tradition in sediment provenance studies (Taylor and McLennan, 1985; Bhatia and Crook, 1986; Olivarez et al., 1991; Muhs et al., 2007a,b; Ziegler et al., 2007). To this we also add Sc-Th-Zr and Sc-Th-Ta diagrams. Bhatia and Crook (1986) point out that Sc-Th-Zr provides discriminating power for source sediments that is complimentary to Sc-Th-La. We also use Sc-Th-Ta because this element suite helps discriminate between two potential source sediments, African dust and Mississippi loess, that $\mathrm{Sc}-\mathrm{Th}-\mathrm{La}$ and Sc-Th-Zr do not differentiate. Muhs et al. (2007a) report that $\mathrm{Cr}-\mathrm{Th}-\mathrm{Nd}$ also has resolving power for some of the source materials considered here.

On a Sc-Th-La diagram, African dust and Mississippi loess overlap, but Lesser Antilles tephras and Central American tephras are easily discriminated from one another (Fig. 13). The $\mathrm{Sc}-\mathrm{Th}-\mathrm{Zr}$ diagram shows good separation of fields for Lesser Antilles tephras and the two eolian sources, African dust and Mississippi loess. There are too few $\mathrm{Zr}$ data in Drexler et al. (1980) for assessing Central American tephras, however. African dust,
Mississippi loess and Lesser Antilles tephras are all well differentiated on Sc-Th-Ta plots.

Based on the trace element data, Jamaican soils appear to be derived from a mix of at least two sources, most likely African dust and Lesser Antilles tephras, and some third, as yet unidentified source (Fig. 13). Many soils plot within the Lesser Antilles field for $\mathrm{Sc}-\mathrm{Th}-\mathrm{Zr}$, but most are closer to African dust for Sc-Th-La. The Sc-Th-La diagram indicates little input from Central American tephras. On the Sc-Th-Ta diagram, Jamaican soils plot mostly between the African dust and Lesser Antilles tephra fields. Finally, on the $\mathrm{Cr}-\mathrm{Th}-\mathrm{Nd}$ diagram, Jamaican soils plot well outside the fields of Lesser Antilles tephras, Mississippi loess and African dust, but plot closest to African dust. Nevertheless, the spread of points indicates that some unidentified, high-Cr (mafic?) source must also contribute to the soils.

\subsection{REE as provenance indicators}

Certain parameters have been developed that reduce REE data and facilitate comparisons in provenance studies. A common way to do this is to compare the abundance of light (LREE), middle (MREE), and heavy (HREE) rare earths, using a representative element for each group. For example, Nakai et al. (1993) use La/Yb and Sun (2002) uses $\mathrm{Ce} / \mathrm{Yb}$ to compare the abundance of LREE to HREE.

In studying possible sources for Jamaican soils, we wished to limit our consideration of tephra sources only to 

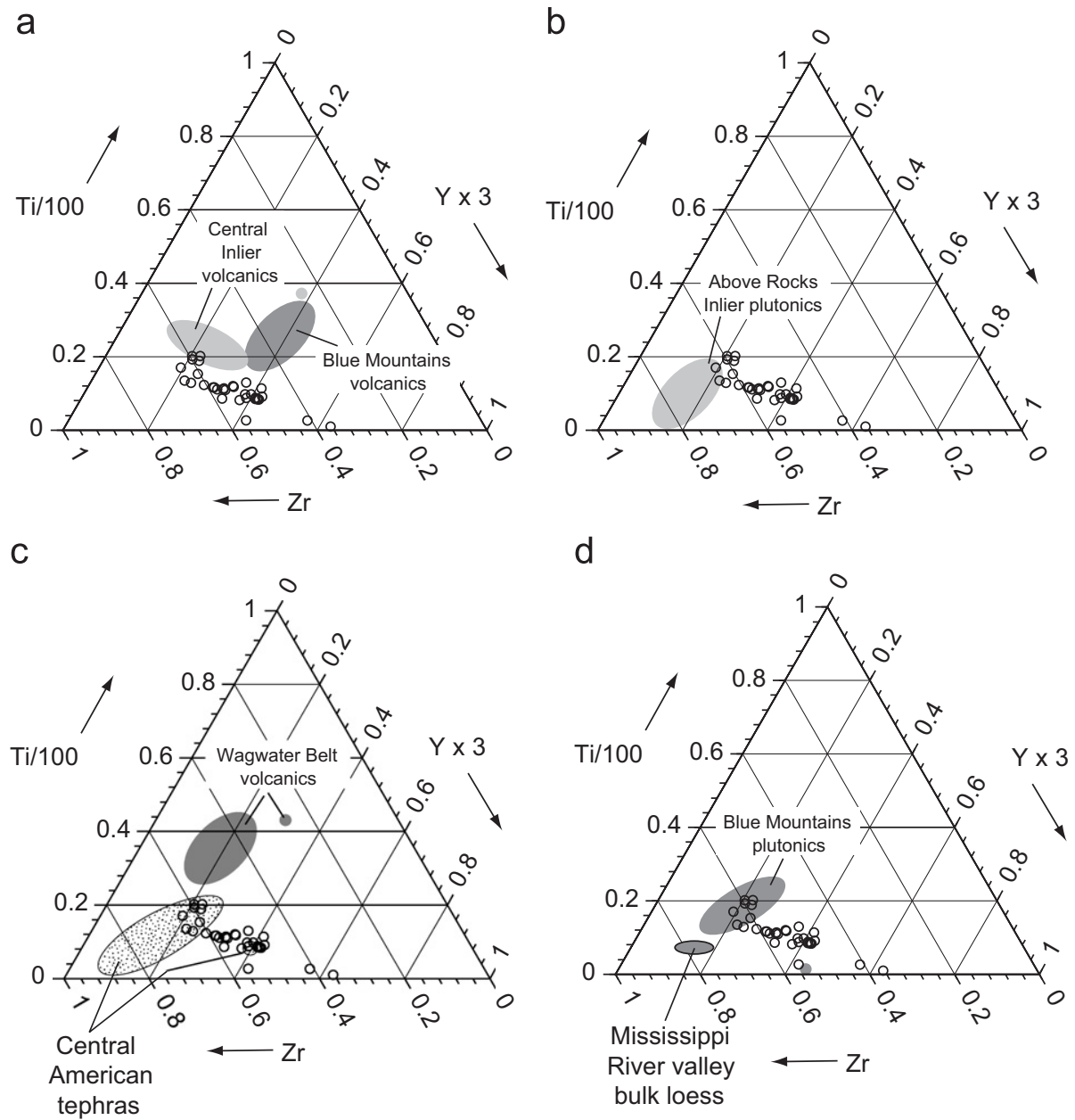

Fig. 12. Ternary diagrams of Ti-Zr-Y in Jamaican soils (shown as open circles; data from this study). Also shown for comparison are polygons showing the range of variation of these elements in local igneous bedrock (igneous rock bodies shown in Fig. 2), Central American tephras, and Mississippi River bulk loess. Geochemical data for igneous rocks are from Jackson et al. (1989) and Jackson and Scott (2002); data for Central American tephras are from Clift et al. (2005); data for bulk Mississippi River valley loess are from Muhs et al. (2001).

those that could have supplied ash to Jamaica during the time of soil formation in our study area. This requires examination only of tephras that are silicic (from explosive eruptions), glass-dominated (far-traveled), and of Quaternary age (the hypothesized ages of the soils studied). For the Lesser Antilles island arc, this includes tephras from Dominica and St. Lucia, reported by Muhs et al. (2007a). The only Central American tephra data of which we are aware that meet all these requirements are those reported in Clift et al. (2005). Their samples consist of silicic, glassdominated tephras of Quaternary age, collected from deepsea cores off the Pacific coast of Costa Rica. Because of the analytical method they used, Clift et al. (2005) have data only for certain REE. Thus, we use $\mathrm{La} / \mathrm{Yb}$ (for LREE to HREE) and $\mathrm{Sm} / \mathrm{Yb}$ (for MREE to HREE), elements common to all data sets considered here.

An earlier study by Drexler et al. (1980) shows that Central American tephras of late Quaternary age tend to be LREE-enriched. The later study by Clift et al. (2005), using tephras that span the entire Quaternary, is consistent with these results. Central American tephras have very high
$\mathrm{Sm}_{\mathrm{N}} / \mathrm{Yb}_{\mathrm{N}}$ and $\mathrm{La}_{\mathrm{N}} / \mathrm{Yb}_{\mathrm{N}}$ (where the subscript "N" indicates chondrite normalized) and define a compositional field that has little overlap with Jamaican soils (Fig. 14). We conclude from these data that Central American tephras, even though highly explosive and capable of being transported eastward on the upper tropospheric westerlies, apparently have played little or no role in Quaternary soil genesis on Jamaica. In contrast, $\mathrm{Sm}_{\mathrm{N}} / \mathrm{Yb}_{\mathrm{N}}$ and $\mathrm{La}_{\mathrm{N}} / \mathrm{Yb}_{\mathrm{N}}$ values for Lesser Antilles tephras, Mississippi loess, and African dust are all much lower (Fig. 14). Although these three source sediments have only partial overlap, Jamaican soils could conceivably have been derived from some mix of the three sources. Thus, although we can conclude from $\mathrm{Sm}_{\mathrm{N}} / \mathrm{Yb}_{\mathrm{N}}$ vs. $\mathrm{La}_{\mathrm{N}} / \mathrm{Yb}_{\mathrm{N}}$ that Central American tephra is not a likely source material, other REE parameters are necessary to discriminate the other three source materials.

One particularly sensitive REE parameter for provenance studies is the Eu anomaly, described earlier. Volcanic rocks or tephras without a significant continental-crustal component will have no Eu anomaly. Archean sedimentary rocks usually have positive $\mathrm{Eu}$ anomalies, but post- 

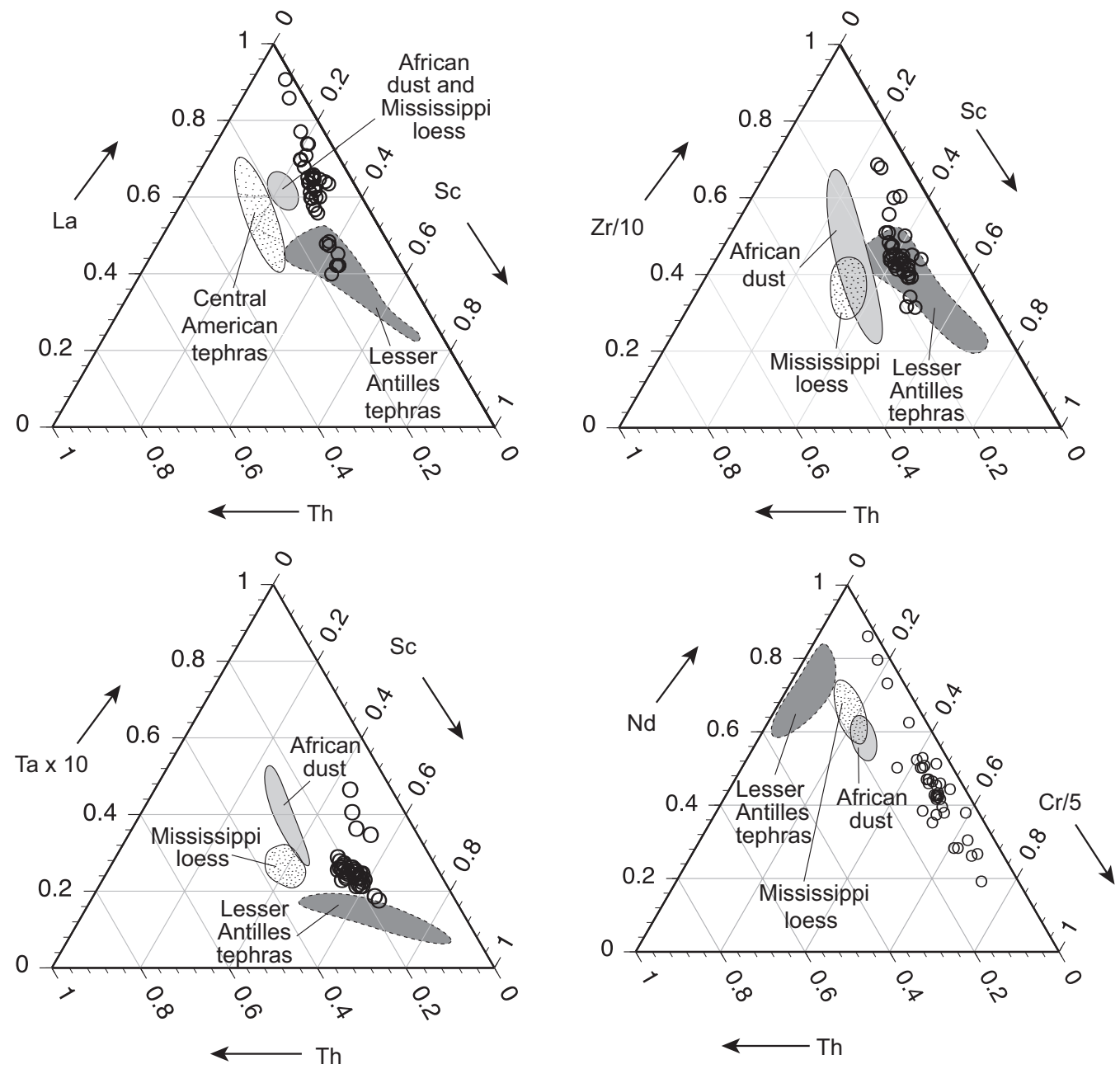

Fig. 13. Ternary diagrams for Sc-Th-La, Sc-Th-Zr, Sc-Th-Ta, and Cr-Th-Nd showing composition of Jamaican soils (shown as open circles; data from this study) and possible source sediments (data for all source sediments from Muhs et al. (2007a), except for Central American tephras, from Drexler et al., 1980).

Archean sedimentary rocks typically have negative Eu anomalies, with $\mathrm{Eu} / \mathrm{Eu}^{*}$ values ranging from 0.6 to just under 1.0 (Taylor and McLennan, 1985, 1995; McLennan, 1989). These differences reflect the fact that Archean and post-Archean continental crusts had significant differences in composition, possibly related to different mantle sources or mechanisms of crustal differentiation. Chinese and Alaskan loesses of Quaternary age have $\mathrm{Eu} / \mathrm{Eu}^{*}$ values that range from 0.58 to 0.68 , and are very similar to postArchean sedimentary rocks (Gallet et al., 1996; Jahn et al., 2001; Muhs and Budahn, 2006).

Two other measures of REE composition reflect the differences in abundances of light-to-heavy REE. The ratio $\mathrm{La}_{\mathrm{N}} / \mathrm{Yb}_{\mathrm{N}}$ is a measure of the overall abundances of light REE to heavy REE, and higher $\mathrm{La}_{\mathrm{N}} / \mathrm{Yb}_{\mathrm{N}}$ values indicate light REE enrichment. Typical post-Archean sedimentary rocks have REE compositions that yield $\mathrm{La}_{\mathrm{N}} / \mathrm{Yb}_{\mathrm{N}}$ values less than about 15 (Taylor and McLennan, 1985, 1995; McLennan, 1989). Chinese and Alaskan loesses have, for example, $\mathrm{La}_{\mathrm{N}} / \mathrm{Yb}_{\mathrm{N}}$ values that range from about 7 to 10 (Gallet et al., 1996; Jahn et al., 2001; Muhs and Budahn,
2006). In addition, high $\mathrm{Gd}_{\mathrm{N}} / \mathrm{Yb}_{\mathrm{N}}$ indicate significant heavy REE depletion. Thus, plots of $\mathrm{Eu} / \mathrm{Eu}^{*}$ vs. $\mathrm{La}_{\mathrm{N}} / \mathrm{Yb}_{\mathrm{N}}$ and $\mathrm{Eu} / \mathrm{Eu}^{*}$ vs. $\mathrm{Gd}_{\mathrm{N}} / \mathrm{Yb}_{\mathrm{N}}$ help define REE compositional fields that are distinctive for sediments that have diverse origins. These REE pairs were used by Nakai et al. (1993) in studying the origin of eolian dust in deep-sea sediments of the Pacific Ocean, and by Sun (2002), in examining the sources of loess in China.

Values of $\mathrm{Eu} / \mathrm{Eu} *, \mathrm{La}_{\mathrm{N}} / \mathrm{Yb}_{\mathrm{N}}$ and $\mathrm{Gd}_{\mathrm{N}} / \mathrm{Yb}_{\mathrm{N}}$ are distinct for the some of the soil parent materials considered here (Fig. 15). Fields defined by African dust and lower Mississippi River valley loess have considerable overlap, but African dust has generally higher $\mathrm{Eu} / \mathrm{Eu}^{*}$. There is some overlap between the fields defined by African dust and Lesser Antilles tephras, but it is minimal, particularly on the $\mathrm{Eu} / \mathrm{Eu}^{*}$ vs. $\mathrm{La}_{\mathrm{N}} / \mathrm{Yb}_{\mathrm{N}}$ plot. On both plots, the fields for Mississippi River valley loess and Lesser Antilles tephras do not overlap at all.

Soils on Jamaica have $\mathrm{Eu} / \mathrm{Eu}^{*}$ values similar to the range found for Barbados samples (Muhs et al., 2007a), have a close overlap with African dust and a partial overlap with 

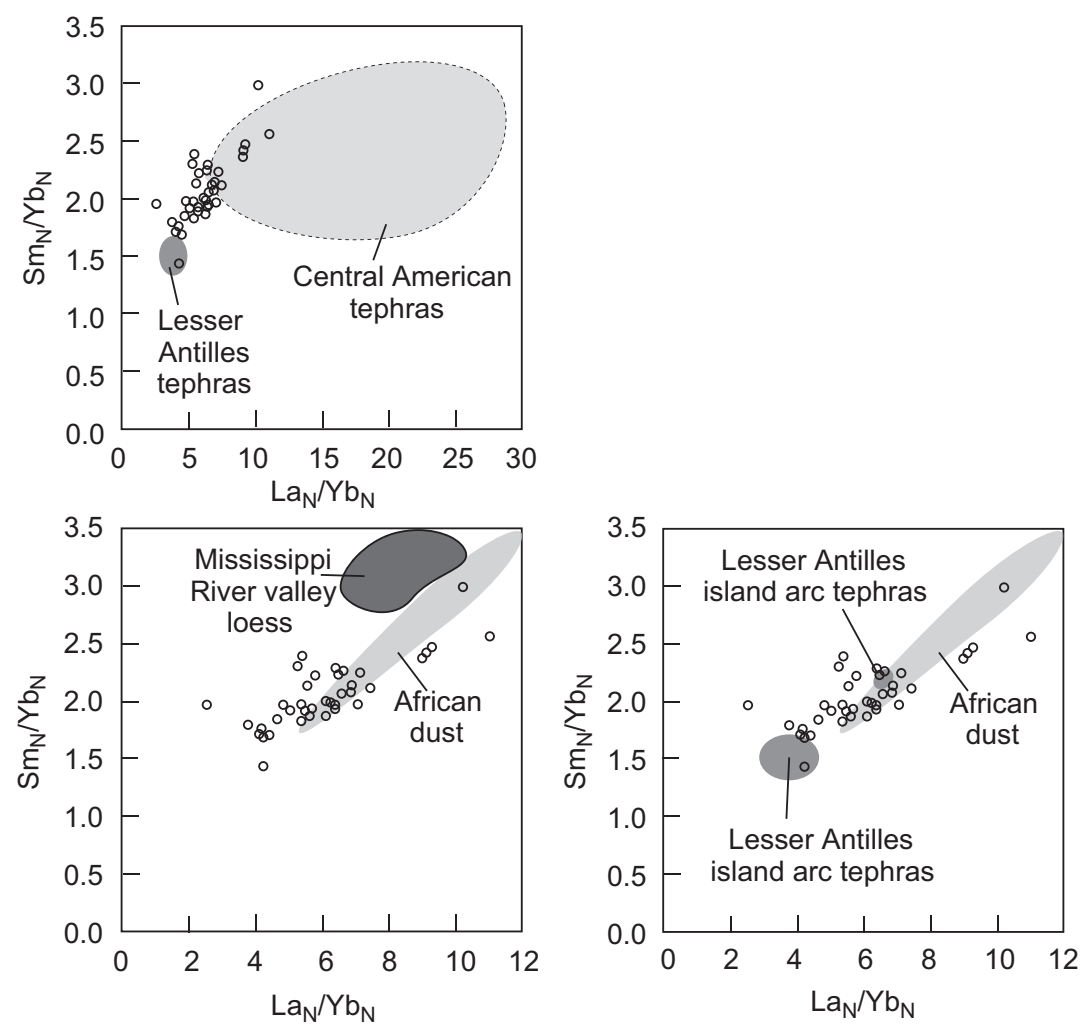

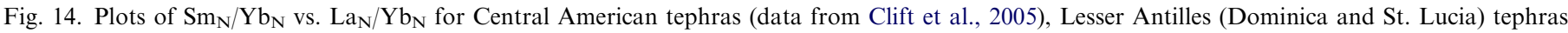

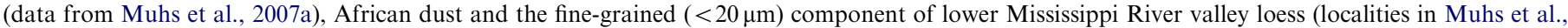
2001; data from Muhs et al., 2007a), and Jamaican soils, shown as circles (this study).

the field defined by Lesser Antilles tephras. Jamaican soils, as well as Barbados soils, have $\mathrm{Eu} / \mathrm{Eu}^{*}$ values that are lower than most of the field defined by Lesser Antilles tephras and higher than those from distal loess of the Mississippi River valley. Unlike Barbados soils, Jamaican soils show generally higher values (and a much greater range) for $\mathrm{La}_{\mathrm{N}} / \mathrm{Yb}_{\mathrm{N}}$ and $\mathrm{Gd}_{\mathrm{N}} / \mathrm{Yb}_{\mathrm{N}}$. Although $\mathrm{La}_{\mathrm{N}} / \mathrm{Yb}_{\mathrm{N}}$ and $\mathrm{Gd}_{\mathrm{N}} / \mathrm{Yb}_{\mathrm{N}}$ values for some Jamaican soils overlap the field for Lesser Antilles tephras, there is closer agreement with the range for African dust, particularly on $\mathrm{Eu} / \mathrm{Eu}^{*}$ vs. $\mathrm{Gd}_{\mathrm{N}} / \mathrm{Yb}_{\mathrm{N}}$. Jamaican soils have no overlap with the field defined by Mississippi River valley loess.

\section{Discussion}

\subsection{Soil trends with hypothesized ages}

The major element abundances in soils on the northern coast of Jamaica show evidence of considerable chemical weathering over time. The abundance of primary rockforming minerals in these soils appears to be relatively low, based on low amounts of $\mathrm{K}_{2} \mathrm{O}$ and $\mathrm{Na}_{2} \mathrm{O}$, two elements that reflect the concentrations of feldspars and micas. Instead, XRD analyses of the clay fractions show that the mineral suite is dominated by secondary, phyllosilicate clay minerals. Clay minerals in soils on the younger terraces (WR-A, B and RN-1, 2A, 2B) are, with one unexplained exception (RN-3) dominated by kaolinite. Clay minerals in soils on the higher terrace (OR-4A and OR-4B) have considerable kaolinite and in addition contain significant amounts of boehmite.

The change in clay mineralogy over time is reflected in progressive loss of $\mathrm{Si}$ with concomitant accumulation of $\mathrm{Al}$. Soils on the younger terraces (RN-1, 2A, 2B; WR-A, B) have relatively high $\mathrm{SiO}_{2} / \mathrm{Al}_{2} \mathrm{O}_{3}$ values, whereas these values are low in soils on the high terrace (OR-4A, B). The $\mathrm{SiO}_{2}$ / $\mathrm{Al}_{2} \mathrm{O}_{3}$ values for the younger soils are comparable to those for soils on middle-to-late Quaternary-age reef terraces of Barbados (Muhs, 2001). The older soils on Jamaica have $\mathrm{SiO}_{2} / \mathrm{Al}_{2} \mathrm{O}_{3}$ values similar to those of soils on relatively pure Quaternary carbonate eolianites on the Bahamas (Foos, 1991) and Bermuda (Herwitz and Muhs, 1995).

Jamaican soils show redder colors and higher $\mathrm{Fe}_{2} \mathrm{O}_{3}$ contents with age. Low-terrace soils have mostly 10YR or 7.5YR hues (although WR-A has 5YR hues), intermediate-elevation terrace soils (RN-2A, B) have mostly 5YR and 2.5YR hues, and the high-terrace soils (OR-4A, B) have 10R hues. This trend in color is mirrored by increasing total $\mathrm{Fe}_{2} \mathrm{O}_{3}$ contents with relative age, suggesting that much of the $\mathrm{Fe}$ in these soils is in the form of hematite. It is common for soils to become redder over time, a reflection of increasing hematite accumulation as a secondary product, at the expense of loss of primary minerals (Birkeland, 1999). Garrett and Lalor (2005) made 

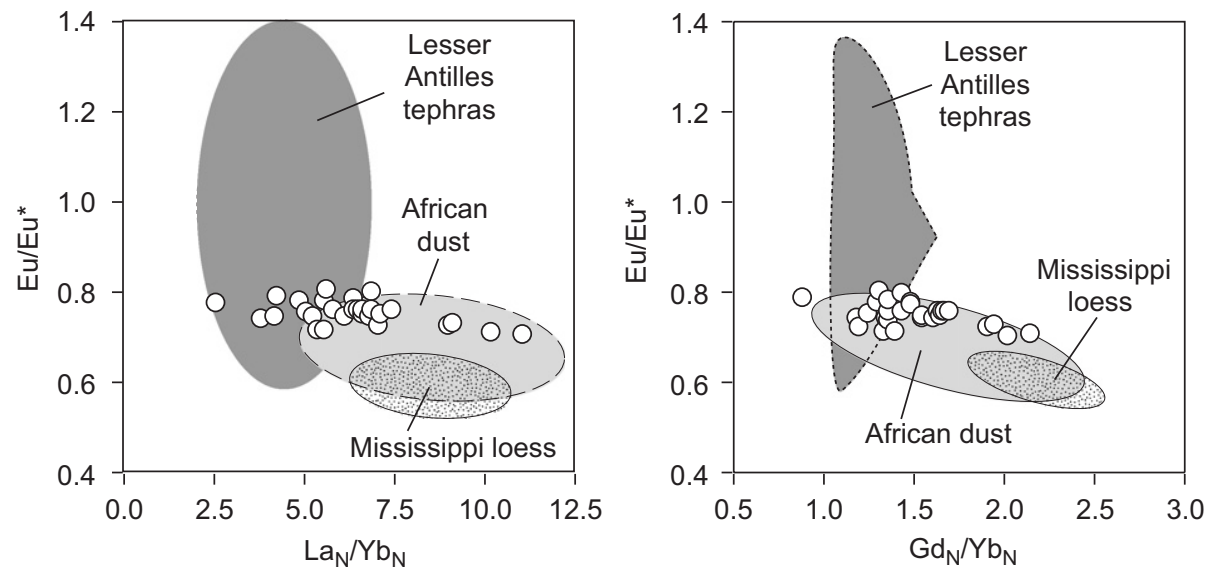

Fig. 15. (a) Plot of Eu/Eu* vs. $\mathrm{La}_{\mathrm{N}} / \mathrm{Yb}_{\mathrm{N}}$ for Jamaican soils (shown as circles) and ranges of these values (shown as ellipses) from Lesser Antilles (Dominica and St. Lucia) tephras, African dust, and the fine-grained $(<20 \mu \mathrm{m})$ component of lower Mississippi River valley loess. (b) Plots of Eu/Eu* vs. $\mathrm{Gd}_{\mathrm{N}} / \mathrm{Yb}_{\mathrm{N}}$ for Jamaican soils (shown as circles) and ranges of these values (shown as ellipses) from tephras from Dominica and St. Lucia, Saharan dust, and lower Mississippi River valley loess. Data for possible soil parent materials in both plots are from Muhs et al. (2007a).

similar observations for Fe accumulation in other Jamaican soils.

Despite the high degree of chemical weathering that these soils seem to have experienced, none that we studied has a major element geochemistry that resembles highgrade Jamaican bauxite. Lyew-Ayee (1984) summarizes the mineralogy and geochemistry of Jamaican bauxite. Many of the minerals found in Jamaican bauxites - gibbsite, boehmite, kaolinite, hematite, and goethite - are identified in or inferred to be present in the soils we studied. However, with the exception of the oldest soils we studied (OR-4A and OR-4B), Jamaican bauxites have much higher $\mathrm{Al}_{2} \mathrm{O}_{3}$ contents $(\sim 44-47 \%)$, higher $\mathrm{Fe}_{2} \mathrm{O}_{3}$ contents $(\sim 17-19 \%)$, and lower $\mathrm{SiO}_{2}$ contents $(\sim 0.3-1.5 \%)$. The high $\mathrm{Al}_{2} \mathrm{O}_{3}$ contents and extremely low $\mathrm{SiO}_{2}$ contents reflect the high concentrations of gibbsite and boehmite, the major $\mathrm{Al}_{2} \mathrm{O}_{3}$-bearing minerals, and low concentrations of kaolinite, the major $\mathrm{SiO}_{2}$-bearing mineral. Hence, $\mathrm{SiO}_{2} /$ $\mathrm{Al}_{2} \mathrm{O}_{3}$ values in bauxite are very low, on the order of $0.15-0.01$.

\subsection{Sources of Jamaican soils from geochemistry}

Major element geochemistry, using $\mathrm{CaO}+\mathrm{LOI}$ as an indicator of carbonate content, shows that Quaternary limestones of Jamaica are very pure carbonate rocks. Thus, it is unlikely that the terra rossa soils of Jamaica formed by the accumulation of insoluble residues. If this were true, there should also be field evidence of significant carbonate dissolution on the Quaternary limestones. Although there is abundant evidence of limestone dissolution on Jamaica, in the form of spectacular karst geomorphology, these landforms are found mostly on the older, Tertiary limestones.

Immobile element suites, using $\mathrm{Ti}-\mathrm{Zr}-\mathrm{Y}$, suggest that local igneous rocks cannot explain the origin of terra rossa soils on Jamaica. In theory, local volcanic and plutonic rocks could be eroded from higher-elevation points on the island and transported onto lower-elevation carbonate surfaces. This material could then weather to form the terra rossa soils. However, Ti-Zr-Y plots show little overlap between local igneous rocks and terra rossa soils on Jamaica.

Immobile trace element geochemistry suggests that terra rossa soils on Jamaica have formed from more than one external parent material. Tephras from the active Quaternary volcanoes in the Central American arc are a potential source, but a plot of $\mathrm{Sm}_{\mathrm{N}} / \mathrm{Yb}_{\mathrm{N}}$ vs. $\mathrm{La}_{\mathrm{N}} / \mathrm{Yb}_{\mathrm{N}}$ shows that this is not likely. However, the same plot indicates that a combination of African dust and Lesser Antilles island arc material could explain the composition of Jamaican soils. This interpretation is supported by Sc-Th-La, Sc-Th-Zr, and Sc-Th-Ta plots. Plots of $\mathrm{Eu} / \mathrm{Eu}^{*}$ vs. $\mathrm{La}_{\mathrm{N}} / \mathrm{Yb}_{\mathrm{N}}$ and $\mathrm{Eu} / \mathrm{Eu}^{*}$ vs. $\mathrm{Gd}_{\mathrm{N}} / \mathrm{Yb}_{\mathrm{N}}$ show that Jamaican soils have some overlap with the field defined by Lesser Antilles island arc tephras and considerable overlap with African dust. However, $\mathrm{Cr}-\mathrm{Th}-\mathrm{Nd}$ indicates that some high-Cr (likely mafic) source must also contribute to the soils. Thus, on the basis of all these data, we believe that Jamaican soils could be derived from some mix of African dust, Lesser Antilles tephra, and at least one other (mafic) source, as yet unidentified.

\subsection{Comparison of Jamaican soils with African dust trajectory and flux modeling}

Although we are not aware of any ground-based measurements of dust fall on Jamaica, back-trajectory calculations of dust that reaches the southeastern United States suggest that African dust almost certainly passes over and affects Jamaica (Perry et al., 1997). In addition, there have been at least two recent efforts to model African dust generation and transport across the Atlantic Ocean (Kallos et al., 2006; Mahowald et al., 2006). The model 
presented by Kallos et al. (2006) indicates that African dust easily reaches Jamaica and points farther west at the same latitude. Mahowald et al. (2006) modeled dust generation on a global basis during both interglacial (present) and lastglacial ( $\sim 21 \mathrm{ka})$ periods. Their models indicate that African dust reaches Jamaica during both glacial and interglacial climatic regimes, but North American dust does not. The dust models of Mahowald et al. (2006) further suggest possible fluxes of around $2-5 \mathrm{~g} \mathrm{~m}^{-2} \mathrm{yr}^{-1}$ in the vicinity of Jamaica during the present interglacial period and fluxes of perhaps $5-10 \mathrm{~g} \mathrm{~m}^{-2} \mathrm{yr}^{-1}$ during the last glacial period. The higher flux of African dust to the Atlantic Ocean during the last glacial period has been well documented from studies of deep-sea cores (see summaries by Mahowald et al., 1999; Kohfeld and Tegen, 2007). Because even the youngest soils we studied, RN-1, WR-A, and WR-B, are found on the last-interglacial Falmouth Formation, all soils in the present work would have been affected by both glacial and interglacial African dust flux rates.

\subsection{Implications for bauxite genesis}

The results presented here may have implications for bauxite genesis on Jamaica and elsewhere. A persistent problem in bauxite genesis has been the origin of $\mathrm{Si}, \mathrm{Al}$, and $\mathrm{Fe}$ in these deposits whereas they are usually present only in small amounts in the host limestone. Accumulation of insoluble residues often requires unrealistic or even impossible amounts of carbonate dissolution, as discussed earlier. Fluvial additions often do not explain bauxite genesis where such deposits are found on uplands; this mechanism also begs the question of how the bauxitic deposits, later transported, formed in the first place. Thus, in the past few decades, there is an increasing recognition that external sources, such as volcanic ash (Comer, 1974, 1984; Comer et al., 1980) or airborne dust (Lyew-Ayee, 1984; Brimhall, 1988; Pye, 1988) must play a role in bauxite genesis.

The geochemical studies of Quaternary, terra rossa-type soils on Jamaica, reported here, suggest that both volcanic ash and airborne dust may play important roles in soil genesis on relatively pure Quaternary limestones. Although these soils do not have the high $\mathrm{Al}_{2} \mathrm{O}_{3}$ and $\mathrm{Fe}_{2} \mathrm{O}_{3}$ contents and low $\mathrm{SiO}_{2}$ contents of Jamaican bauxites, they are nevertheless far closer in composition to bauxites than are typical, mid-latitude soils of Quaternary age (see examples in Birkeland, 1999). We suggest, therefore, that the soils on Quaternary limestones on the northern coast of Jamaica may represent the early stages of bauxite formation, derived from a combination of high-Al-and-Fe airborne dust from Africa and high-Si, tephra-derived glass from the Lesser Antilles island arc.

\section{Conclusions}

Reddish-brown or red terra rossa soils are found on emergent limestones of probable Quaternary age on the northern coast of Jamaica. The soils show progressive changes in development that are expressed in morphology, mineralogy, and geochemistry, and indicate increasing thickness, loss of mobile constituents, accumulation of immobile constituents, and mineral alteration over time. The soils have a composition that suggests they may be precursors to the older, well-developed, aluminum-rich bauxites found elsewhere on Jamaica. Because the host limestones are relatively pure, accumulation of insoluble residues is not a likely pathway of soil formation. Trace element geochemistry also indicates that local volcanic and plutonic rocks play a minor role, if any, in soil genesis. Rare earth elements and suites of other trace elements indicate that Jamaican soils have probably formed from at least two, and possibly three extraneous parent materials. Most geochemical data indicate that the soils formed primarily by alteration of a combination of volcanic ash from the Lesser Antilles island arc and airborne dust from Africa.

\section{Acknowledgments}

This study was supported by the Earth Surface Dynamics Program of the US Geological Survey, and is a contribution to the "Eolian History of North America" project. We thank Ludwig Zöeller for inviting us to provide this contribution. Original fieldwork was conducted in 1985 with support from the University of Wisconsin. Tracy Rowland ably assisted with all the fieldwork. We thank Scott Cowherd (then of the US Geological Survey), who provided most of the X-ray diffraction data and Gary Skipp (US Geological Survey), who X-rayed the silica nodules. Trevor Jackson (University of the West Indies) provided helpful background on Jamaican geology, which we appreciate. We are grateful to Michael Machette and Joan Fitzpatrick (both of the US Geological Survey) who provided very constructive reviews of an earlier version of the paper.

\section{References}

Ahmad, N., Jones, R.L., Beavers, A.H., 1966. Genesis, mineralogy and related properties of West Indian soils: I. Bauxitic soils of Jamaica. Soil Science Society of America Proceedings 30, 719-722.

Bettis Jr., E.A., Muhs, D.R., Roberts, H.M., Wintle, A.G., 2003. Last glacial loess in the conterminous USA. Quaternary Science Reviews 22, 1907-1946.

Bhatia, M.R., Crook, K.A.W., 1986. Trace element characteristics of graywackes and tectonic setting discrimination of sedimentary basins. Contributions to Mineralogy and Petrology 92, 181-193.

Birkeland, P.W., 1999. Soils and Geomorphology. Oxford University Press, London, 430pp.

Borg, L.E., Banner, J.L., 1996. Neodymium and strontium isotopic constraints on soil sources in Barbados, West Indies. Geochimica et Cosmochimica Acta 60, 4193-4206.

Boss, S.K., Liddell, W.D., 1987. Back-reef and fore-reef analogs in the Pleistocene of north Jamaica: implications for facies recognition and sediment flux in fossil reefs. Palaios 2, 219-228. 
Boulegue, J., Benedetti, M., Bildgen, P., 1989. Geochemistry of waters associated with current karst bauxite formation, southern peninsula of Haiti. Applied Geochemistry 4, 37-47.

Brimhall, G.H., Lewis, C.J., Ague, J.J., Dietrich, W.E., Hampel, J., Teague, T., Rix, P., 1988. Metal enrichment in bauxites by deposition of chemically mature aeolian dust. Nature $333,819-824$

Budahn, J.R., Schmitt, R.A., 1985. Petrogenetic modeling of Hawaiian tholeiitic basalts: a geochemical approach. Geochimica et Cosmochimica Acta 49, 67-87.

Budahn, J.R., Wandless, G.A., 2002. Instrumental neutron activation by long count. US Geological Survey Open-File Report OF 02-0223, pp. X1-X13.

Burke, K., Grippi, J., Sengör, A.M.C., 1980. Neogene structures in Jamaica and the tectonic style of the northern Caribbean plate boundary zone. Journal of Geology 88, 375-386.

Burns, D.J., 1961. Some chemical aspects of bauxite genesis in Jamaica. Economic Geology 56, 1297-1303.

Cant, R.V., 1970. Pleistocene terraces near Oracabessa. International Field Institute Guidebook to the Caribbean Island-Arc System. American Geological Institute, Washington, DC, pp. 40-43.

Cant, R.V., 1972. Jamaica's Pleistocene reef terraces. Journal of the Geological Society of Jamaica 12, 13-17.

Cant, R.V., 1973. Jamaica's Pleistocene reef terraces. Geologie en Mijnbouw 52, 157-160.

Caquineau, S., Gaudichet, A., Gomes, L., Legrand, M., 2002. Mineralogy of Saharan dust transported over northwestern tropical Atlantic Ocean in relation to source regions. Journal of Geophysical Research 107 (D15), 4251.

Carey, S.N., Sigurdsson, H., 1980. The Roseau ash: deep-sea tephra deposits from a major eruption on Dominica, Lesser Antilles arc. Journal of Volcanology and Geothermal Research 7, 67-86.

Chubb, L.J., 1963. Bauxite genesis in Jamaica. Economic Geology 58, 286-289.

Clarke, O.M., 1966. The formation of bauxite on karst topography in the Eufaula district, Alabama, and Jamaica. Economic Geology 61, 903-916.

Clift, P.D., Chan, L.-H., Blusztajn, J., Layne, G.D., Kastner, M., Kelly, R.K., 2005. Pulsed subduction accretion and tectonic erosion reconstructed since $2.5 \mathrm{Ma}$ from the tephra record offshore Costa Rica. Geochemistry, Geophysics, Geosystems 6, 21pp.

Comer, J.B., 1974. Genesis of Jamaican bauxite. Economic Geology 69, $1251-1264$

Comer, J.B., 1984. Geological and geochemical constraints on the origin of bauxite in Jamaica. In: Jacob, Jr., L. (Ed.), Bauxite: Proceedings of the 1984 Bauxite Symposium, Los Angeles, California, February 27-March 1, 1984. American Institute of Mining, Metallurgical, and Petroleum Engineers, Inc., New York, pp. 152-164.

Comer, J.B., Naeser, C.W., McDowell, F.W., 1980. Fission-track ages of zircon from Jamaican bauxite and terra rossa. Economic Geology 75 , $117-121$.

Drexler, J.W., Rose, W.I., Sparks, R.S.J., Ledbetter, M.T., 1980. The Los Chocoyos Ash, Guatemala: a major stratigraphic marker in middle America and in three ocean basins. Quaternary Research 13, $327-345$.

Foos, A.M., 1991. Aluminous lateritic soils, Eleuthera, Bahamas: a modern analog to carbonate paleosols. Journal of Sedimentary Petrology 61, 340-348.

Gallet, S., Jahn, B., Torii, M., 1996. Geochemical characterization of the Luochuan loess-paleosol sequence, China, and paleoclimatic implications. Chemical Geology 133, 67-88.

Gallet, S., Jahn, B., Van Vliet-Lanoe, B., Dia, A., Rossello, E.A., 1998. Loess geochemistry and its implications for particle origin and composition of the upper continental crust. Earth and Planetary Science Letters 156, 157-172.

Garrett, R.G., Lalor, G.C., 2005. The Fe/Na ratio, a framework for modeling trace element distributions in Jamaican soils. Geochemistry: Exploration, Environment, Analysis 5, 147-157.
Garrett, R.G., Lalor, G.C., Vutchkov, M., 2004. Geochemical exploration for gold in Jamaica: a comparison of stream sediment and soil surveys. Geochemistry: Exploration, Environment, Analysis 4, $161-170$.

Goudie, A.S., Middleton, N.J., 2001. Saharan dust storms: nature and consequences. Earth-Science Reviews 56, 179-204.

Hartman, J.A., 1955. Origin of heavy minerals in Jamaican bauxite. Economic Geology 50, 738-747.

Henry, L.A., 1978a. Port Maria: Geological Sheet 21, Mines and Geology Division, Jamaica Ministry of Mining and Natural Resources, scale1:50,000.

Henry, L.A., 1978b. Ocho Rios: Geological Sheet 18, Mines and Geology Division, Jamaica Ministry of Mining and Natural Resources, scale 1:50,000.

Herwitz, S.R., Muhs, D.R., 1995. Bermuda solution pipe soils: a geochemical evaluation of eolian parent materials. Geological Society of America Special Paper 300, 311-323.

Hill, V.G., 1955. The mineralogy and genesis of bauxite deposits of Jamaica. B.W.I. American Mineralogist 40, 676-688.

Holser, W.T., 1997. Evaluation of the application of rare-earth elements to paleoceanography. Palaeogeography, Palaeoclimatology, Palaeoecology 132, 309-323.

Horsfield, W.T., 1973. Late Tertiary and Quaternary crustal movements in Jamaica. Journal of the Geological Society of Jamaica 13, 6-13.

Horsfield, W.T., 1975. Quaternary vertical movements in the Greater Antilles. Geological Society of America Bulletin 86, 933-938.

Hose, H.R., 1963. Jamaica type bauxites developed on limestones. Economic Geology 58, 63-69.

Imbrie, J., Hays, J.D., Martinson, D.G., McIntyre, A., Mix, A.C., Morley, J.J., Pisias, N.G., Prell, W.L., Shackleton, N.J., 1984. The orbital theory of Pleistocene climate: support from a revised chronology of the marine $\delta^{18} \mathrm{O}$ record. In: Berger, A., Imbrie, J., Hays, J., Kukla, G., Saltzman, B. (Eds.), Milankovitch and Climate: Understanding the Response to Astronomical Forcing. D. Reidel Publishing Company, Dordrecht, pp. 269-305.

Jackson, T.A., Scott, P.W., 2002. The Paleogene volcanic rocks of Cuba and Jamaica: similarities and differences. In: Jackson, T.A. (Ed.), Caribbean Geology into the Third Millennium: Transactions of the 15th Geological Conference. University of the West Indies Press, Kingston, Jamaica, pp. 107-117.

Jackson, T.A., Smith, T.E., Isaacs, M.C., 1989. The significance of geochemical variations in Cretaceous volcanic and plutonic rocks of intermediate and felsic composition from Jamaica. The Journal of the Geological Society of Jamaica 26, 33-42.

Jahn, B., Gallet, S., Han, J., 2001. Geochemistry of the Xining, Xifeng and Jixian sections, Loess Plateau of China: eolian dust provenance and paleosol evolution during the last $140 \mathrm{ka}$. Chemical Geology 178, 71-94.

Johnson, D.L., 1993. Dynamic denudation evolution of tropical, subtropical and temperate landscapes with three tiered soils: toward a general theory of landscape evolution. Quaternary International 17, $67-78$.

Kallos, G., Papadopoulos, A., Katsafados, P., Nickovic, S., 2006. Transatlantic Saharan dust transport: model simulation and results. Journal of Geophysical Research 111, D09204, doi:10.1029/ 2005JD006207.

Kelly, W.C., 1961. Some data bearing on the origin of Jamaican bauxite. American Journal of Science 259, 288-294.

Kohfeld, K.E., Tegen, I., 2007. Record of mineral aerosols and their role in the Earth system. In: Holland, H.D., Turekian, K.K. (Eds.), Treatise on Geochemistry. Elsevier, 〈http://www.sciencedirect.com/ science/referenceworks/9780080437514 $\rangle, 26 \mathrm{pp}$.

Land, L.S., 1973. Contemporaneous dolomitization of Middle Pleistocene reefs by meteoric water. Bulletin of Marine Science 23, 64-92.

Land, L.S., 1991. Dolomitization of the Hope Gate Formation (north Jamaica) by seawater: reassessment of mixing-zone dolomite. In: Taylor Jr., H.P., O’Neil, J.R., Kaplan, I.R. (Eds.), Stable Isotope 
Geochemistry: A Tribute to Samuel Epstein. Geochemical Society Special Publication No. 3, pp. 121-133.

Land, L.S., Epstein, S., 1970. Late Pleistocene diagenesis and dolomitization, north Jamaica. Sedimentology 14, 187-200.

Lyew-Ayee, P.A., 1984. Bauxites of the Caribbean. In: Jacob Jr., L. (Ed.), Bauxite: Proceedings of the 1984 Bauxite Symposium, Los Angeles, CA February 27-March 1, 1984. American Institute of Mining, Metallurgical, and Petroleum Engineers, Inc., New York, pp. 262-296.

Lyew-Ayee, P.A., Stewart, R., 1982. Stratigraphic and compositional correlations between bauxites and their limestone hosts in Jamaica. Geological Society of Jamaica Journal 7, 19-37.

Mahowald, N., Kohfeld, K., Hansson, M., Balkanski, Y., Harrison, S.P., Prentice, I.C., Schulz, M., Rodhe, H., 1999. Dust sources and deposition during the last glacial maximum and current climate: a comparison of model results with paleodata from ice cores and marine sediments. Journal of Geophysical Research 104, $15,895-15,916$.

Mahowald, N., Muhs, D.R., Levis, S., Yoshioka, M., Zender, C., Rasch, P., 2006. Change in atmospheric mineral aerosols in response to climate: last glacial period, pre-industrial, modern and doubled carbon dioxide climates. Journal of Geophysical Research 111, D10202, doi:10.1029/2005JD006653.

Mason, B., Moore, C.B., 1982. Principles of Geochemistry. Wiley, New York, NY, 344pp.

Matson, M., 1984. The 1982 El Chichón volcano eruptions - a satellite perspective. Journal of Volcanology and Geothermal Research 23, $1-10$.

McFarlane, N., 1977. Jamaica-Geology, Mines and Geology Division, Ministry of Mining and Natural Resources, Kingston, Jamaica, scale 1:250,000 (multiple sheets).

McLennan, S.M., 1989. Rare earth elements in sedimentary rocks: influence of provenance and sedimentary processes. Reviews in Mineralogy 21, 169-200.

Moore, D.M., Reynolds, R.C., 1997. X-ray Diffraction and the Identification and Analysis of Clay Minerals, second ed. Oxford University Press, Oxford, 378pp.

Moore, W.S., Somayjulu, B.L.K., 1974. Age determinations of fossil corals using ${ }^{230} \mathrm{Th} /{ }^{234} \mathrm{Th}$ and ${ }^{230} \mathrm{Th} /{ }^{227} \mathrm{Th}$. Journal of Geophysical Research 79, 5065-5068.

Muhs, D.R., 2001. Evolution of soils on Quaternary reef terraces, Barbados, West Indies. Quaternary Research 56, 66-78.

Muhs, D.R., 2002. Evidence for the timing and duration of the last interglacial period from high-precision uranium-series ages of corals on tectonically stable coastlines. Quaternary Research 58, 36- 40 .

Muhs, D.R., Bettis Jr., E.A., 2003. Quaternary loess-paleosol sequences as examples of climate-driven sedimentary extremes. Geological Society of America Special Paper 370, 53-74.

Muhs, D.R., Budahn, J.R., 2006. Geochemical evidence for the origin of late Quaternary loess in central Alaska. Canadian Journal of Earth Sciences 43, 323-337.

Muhs, D.R., Crittenden, R.C., Rosholt, J.N., Bush, C.A., Stewart, K., 1987. Genesis of marine terrace soils, Barbados, West Indies: Evidence from mineralogy and geochemistry. Earth Surface Processes and Landforms 12, 605-618.

Muhs, D.R., Bush, C.A., Stewart, K.C., Rowland, T.R., 1990. Geochemical evidence of Saharan dust parent material for soils developed on Quaternary limestones of Caribbean and western Atlantic islands. Quaternary Research 33, 157-177.

Muhs, D.R., Bettis Jr., E.A., Been, J., McGeehin, J., 2001. Impact of climate and parent material on chemical weathering in loess-derived soils of the Mississippi River Valley. Soil Science Society of America Journal 65, 1761-1777.

Muhs, D.R., Budahn, J., Prospero, J.M., Carey, S.N., 2007a. Geochemical evidence for African dust inputs to soils of western Atlantic islands: Barbados, the Bahamas and Florida. Journal of Geophysical Research 112, F02009, doi:10.1029/2005JF000445.
Muhs, D.R., Budahn, J., Reheis, M., Beann, J., Skipp, G., Fisher, E., 2007b. Airborne dust transport to the eastern Pacific Ocean off southern California: evidence from San Clemente Island. Journal of Geophysical Research 112, D13203, doi:10.1029/2006JD007577.

Nakai, S., Halliday, A.N., Rea, D.K., 1993. Provenance of dust in the Pacific Ocean. Earth and Planetary Science Letters 119, 143-157.

Olivarez, A.M., Owen, R.M., Rea, D.K., 1991. Geochemistry of eolian dust in Pacific pelagic sediments: implications for paleoclimatic interpretations. Geochimica et Cosmochimica Acta 55, 2147-2158.

Patterson, S.H., Kurtz, H.F., Olson, J.C., Neeley, C.L., 1986. World bauxite resources: US Geological Survey Professional Paper 1076-B, $151 \mathrm{pp}$.

Pearce, J.A., Cann, J.R., 1973. Tectonic setting of basic volcanic rocks determined using trace element analyses. Earth and Planetary Science Letters 19, 290-300.

Perry, K.D., Cahill, T.A., Eldred, R.A., Dutcher, D.D., Gill, T.E., 1997. Long-range transport of North African dust to the eastern United States. Journal of Geophysical Research 102, 11,225-11,238.

Prospero, J.M., 1999. Long-term measurements of the transport of African mineral dust to the southeastern United States: Implications for regional air quality. Journal of Geophysical Research 104, $15,917-15,927$.

Prospero, J.M., Carlson, T.N., 1972. Vertical and areal distribution of Saharan dust over the western equatorial North Atlantic Ocean. Journal of Geophysical Research 77, 5255-5265.

Prospero, J.M., Lamb, P.J., 2003. African droughts and dust transport to the Caribbean: Climate change implications. Science 302, 1024-1027.

Prospero, J.M., Nees, R.T., 1986. Impact of the North African drought and El Nino on mineral dust in the Barbados trade winds. Nature 320, 735-738.

Prospero, J.M., Nees, R.T., 1987. Deposition rate of particulate and dissolved aluminum derived from Saharan dust in precipitation at Miami, Florida. Journal of Geophysical Research 92, 14,723-14,731.

Prospero, J.M., Bonatti, E., Schubert, C., Carlson, T.N., 1970. Dust in the Caribbean atmosphere traced to an African dust storm. Earth and Planetary Science Letters 9, 287-293.

Prospero, J.M., Glaccum, R.A., Nees, R.T., 1981. Atmospheric transport of soil dust from Africa to South America. Nature 289, 570-572.

Prospero, J.M., Ginoux, P., Torres, O., Nicholson, S.E., Gill, T.E., 2002. Environmental characterization of global sources of atmospheric soil dust identified with the Nimbus 7 Total Ozone Mapping Spectrometer (TOMS) absorbing aerosol product. Reviews of Geophysics 40 (1), 1002, doi:10.1029/2000RG000095.

Pye, K., 1988. Bauxites gathering dust. Nature 333, 800-801.

Reid, R.P., Carey, S.N., Ross, D.R., 1996. Late Quaternary sedimentation in the Lesser Antilles island arc. Geological Society of America Bulletin 108, 78-101.

Schaetzl, R.J., Anderson, S., 2005. Soils: Genesis and Geomorphology. Cambridge University Press, Cambridge, $817 \mathrm{pp}$.

Schmedeman, O.C., 1948. Caribbean aluminum ores. Engineering and Mining Journal 149, 78-82.

Schmedeman, O.C., 1950. First Caribbean bauxite development, Reynolds Jamaica Mines, Ltd. Engineering and Mining Journal 151, 98-100.

Scholten, J.J., Andriesse, W., 1986. Morphology, genesis and classification of three soils over limestone, Jamaica. Geoderma 39, 1-40.

Sigurdsson, H., Sparks, R.S.J., Carey, S.N., Huang, T.C., 1980. Volcanogenic sedimentation in the Lesser Antilles arc. Journal of Geology 88, 523-540.

Sinclair, I.G.L., 1967. Bauxite genesis in Jamaica: new evidence from trace element distribution. Economic Geology 62, 482-486.

Sinclair, I.G.L., 1976. Genesis of Jamaican bauxite. Economic Geology $71,821-822$.

Speed, R.C., Cheng, H., 2004. Evolution of marine terraces and sea level in the last interglacial, Cave Hill, Barbados. Geological Society of America Bulletin 116, 219-232.

Spell, T.L., McDougall, I., 1992. Revisions to the age of the BrunhesMatuyama boundary and the Pleistocene geomagnetic polarity timescale. Geophysical Research Letters 19, 1181-1184. 
Stemann, T.A., Donovan, S.K., Portell, R.W., 2004. Extant and extinct corals on a late Pliocene reef tract from Jamaica. Geological Society of America Abstracts with Programs 36 (5), 526.

Sun, J., 2002. Provenance of loess material and formation of loess deposits on the Chinese Loess Plateau. Earth and Planetary Science Letters 203, $845-859$.

Szabo, B.J., 1979. ${ }^{230} \mathrm{Th},{ }^{231} \mathrm{~Pa}$, and open system dating of fossil corals and shells. Journal of Geophysical Research 84, 4927-4930.

Taggart Jr., J.E., Lichte, F.E., Wahlberg, J.S., 1982. Methods of analysis of samples using X-ray fluorescence and induction-coupled plasma spectroscopy. US Geological Survey Professional Paper 1250, 683-687.

Taylor, S.R., McLennan, S.M., 1985. The Continental Crust: Its Composition and Evolution. Blackwell Scientific Publications, Oxford, $312 \mathrm{pp}$.

Taylor, S.R., McLennan, S.M., 1995. The geochemical evolution of the continental crust. Reviews of Geophysics 33, 241-265.
Tracey Jr., J.I., Schlanger, S.O., Stark, J.T., Doan, D.B., May, H.G., 1964. General geology of Guam. US Geological Survey Professional Paper 403-A, 104 pp.

Waterman, G.C., 1962. Some chemical aspects of bauxite genesis in Jamaica. Economic Geology 57, 829-830.

Webb, G.E., Kamber, B.S., 2000. Rare earth elements in Holocene reefal microbialites: a new shallow seawater proxy. Geochimica et Cosmochimica Acta 64, 1557-1565.

Zans, V.A., 1959. Recent views on the origin of bauxite. Geonotes 1, 123-132.

Zans, V.A., Chubb, L.J., Versey, H.R., Williams, J.B., Robinson, E., Cooke, D.L., 1962. Synopsis of the geology of Jamaica. Bulletin No. 4, Geological Survey Department, Jamaica, 72pp.

Ziegler, C.L., Murray, R.W., Hovan, S.A., Rea, D.K., 2007. Resolving eolian, volcanogenic, and authigenic components in pelagic sediment from the Pacific Ocean. Earth and Planetary Science Letters 254, 416-432. 